\title{
Blue whale habitat selection and within-season distribution in a regional upwelling system off southern Australia
}

\author{
Peter C. Gill ${ }^{1,2, *}$, Margie G. Morrice ${ }^{1,2}$, Brad Page ${ }^{3}$, Rebecca Pirzl ${ }^{2,4}$, \\ Andrew H. Levings ${ }^{1,2}$, Michael Coyne ${ }^{5}$ \\ ${ }^{1}$ Blue Whale Study, C/- Post Office Narrawong, Victoria 3285, Australia \\ ${ }^{2}$ Deakin University, PO Box 423 Warrnambool, Victoria 3280, Australia \\ ${ }^{3}$ South Australian Research and Development Institute, West Beach, South Australia 5024, Australia \\ ${ }^{4}$ Skadia Pty Ltd, Private Bag 260, Horsham, Victoria 3401, Australia \\ ${ }^{5}$ SEATURTLE.ORG, 1 Southampton Place, Durham, North Carolina 27705, USA
}

\begin{abstract}
Blue whales Balaenoptera musculus aggregate to feed in a regional upwelling system during November-May between the Great Australian Bight (GAB) and Bass Strait. We analysed sightings from aerial surveys over 6 upwelling seasons (2001-02 to 2006-07) to assess within-season patterns of blue whale habitat selection, distribution, and relative abundance. Habitat variables were modelled using a general linear model (GLM) that ranked sea surface temperature (SST) and sea surface chlorophyll (SSC) of equal importance, followed by depth, distance to shore, SSC gradient, distance to shelf break, and SST gradient. Further discrimination by hierarchical partitioning indicated that SST accounted for $84.4 \%$ of variation in blue whale presence explained by the model, and that probability of sightings increased with increasing SST. The large study area was resolved into 3 zones showing diversity of habitat from the shallow narrow shelf and associated surface upwelling of the central zone, to the relatively deep upper slope waters, broad shelf and variable upwelling of the western zone, and the intermediate features of the eastern zone. Density kernel estimation showed a trend in distribution from the west during November-December, spreading south-eastward along the shelf throughout the central and eastern zones during January-April, with the central zone most consistently utilised. Encounter rates in central and eastern zones peaked in February, coinciding with peak upwelling intensity and primary productivity. Blue whales avoided inshore upwelling centres, selecting SST $\sim 1^{\circ} \mathrm{C}$ cooler than remotely sensed ambient SST. Whales selected significantly higher SSC in the central and eastern zones than the western zone, where relative abundance was extremely variable. Most animals departed from the feeding ground by late April.
\end{abstract}

KEY WORDS: Habitat · Distribution $\cdot$ Upwelling $\cdot$ Blue whale $\cdot$ Australia

Resale or republication not permitted without written consent of the publishe

\section{INTRODUCTION}

Long-term management and recovery of endangered baleen whales will depend on our ability to predict their distribution and to protect critical habitat. The role of habitat selection in determining distribution of whales on their foraging grounds is of increasing interest to ecologists, and understanding relationships between seasonal changes in habitat, prey, and whale distribution is a growing area of quantitative research (e.g. Gregr \& Trites 2001, Baumgartner \& Mate 2003, Thiele et al. 2004, Tynan et al. 2005).

Blue whales Balaenoptera musculus aggregate in productive upwelling or frontal regions worldwide to prey on dense but patchy euphausiid aggregations (e.g. Alling et al. 1991, Fiedler et al. 1998, Palacios 1999, Hucke-Gaete et al. 2003, Croll et al. 2005, Etnoyer et al. 2006, Branch et al. 2007), which occur at 
multiple spatio-temporal scales (Watkins 2000). The use of appropriate scales is central to ecological studies (Levin 1992), and scales of oceanographic features that aggregate prey vary greatly, from the macro-scale Antarctic Circumpolar Current (Tynan 1998) to mesoscale coastal upwellings (Croll et al. 2005) and more fine-scale bathymetric features such as individual banks (Stevick et al. 2008).

Blue whales, thought to be pygmy blue whales Balaenoptera musculus brevicauda aggregate each austral summer off southern Australia to prey on the neritic euphausiid Nyctiphanes australis in a meso-scale seasonal cold water upwelling (Gill 2002). The region's most distinctive oceanographic feature is the surface plume of the Bonney Upwelling, which extends west from Cape Nelson $\left(38^{\circ} 26^{\prime} \mathrm{S}, 141^{\circ} 33^{\prime} \mathrm{E}\right)$ to $\sim 138^{\circ} \mathrm{E}$ (Lewis 1981, Schahinger 1987, Nieblas et al. 2009). It is part of a regional upwelling system with an alongshore extent of $\sim 800 \mathrm{~km}$, from an undefined eastern limit near Bass Strait in the east, to the eastern Great Australian Bight (GAB) in the west (Kampf et al. 2004, McClatchie et al. 2006, Ward et al. 2006, Middleton \& Bye 2007) (Fig. 1). This system is influenced by the Flinders Current, the world's only northern boundary current, flowing westward along the continental slope year-round and thought to be upwelling-favourable (Middleton \& Cirano 2002).

Gill $(2002,2004)$ used aerial surveys to confirm the presence of blue whales between Cape Jaffa ( $36^{\circ} 57^{\prime} \mathrm{S}$, $\left.139^{\circ} 41^{\prime} \mathrm{E}\right)$ and Cape Otway (38 $\left.52^{\prime} \mathrm{S}, 143^{\circ} 32^{\prime} \mathrm{E}\right)$, and to establish links between feeding whales and upwelling. During aerial surveys in December 2003, numbers of feeding blue whales were also found in the eastern GAB, showing that the blue whale feeding ground was larger than previously thought (Morrice et al. 2004). Nyctiphanes australis surface swarms were frequently sighted during prior aerial surveys, and their observed distribution closely mirrored that of blue whales (Gill 2002). However, quantitative assessment of $N$. australis' distribution was not feasible from the air due to their tendency to occur at any depth in shelf waters (O'Brien 1988). Also, the cost and temporal biases associated with vessel-based zooplankton surveys at a similar spatial scale precluded their use.

A primary objective of the present study was to use modelling (i.e. general linear model [GLM]) to assess the relative importance of a range of biophysical habitat variables in explaining whale distribution (see Redfern et al. 2006 for a review of cetacean habitat modelling). To do this we used blue whale sighting data from aerial surveys over 6 upwelling seasons, in combination with bathymetric, remote sensing, and temperature logger data. Another objective was to explain within-season patterns of distribution and relative abundance of foraging blue whales in this upwelling system using density kernel estimation and monthly variabililty in encounter rates. Furthermore, the present study presented an opportunity to assess whether the Bonney Upwelling surface plume, representing a shoaling of the thermocline rarely observed

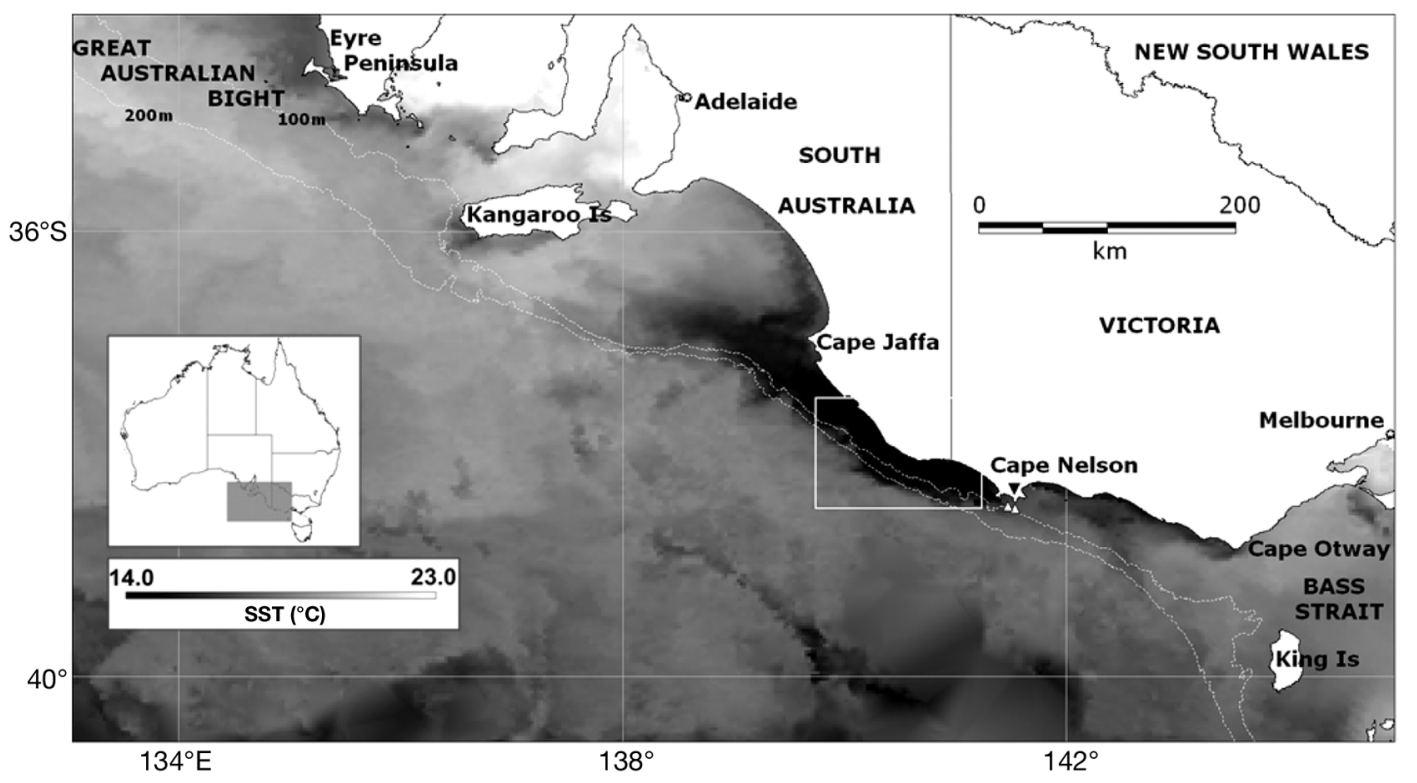

Fig. 1. Study region and average sea surface temperature (SST). The cold (dark) surface plume of the Bonney Upwelling is evident at centre. Less intense upwelling appears inshore between Cape Nelson and Cape Otway, and off southwest Kangaroo Island (Is) and western Eyre Peninsula. Warm water (white) lies in the South Australian gulfs west of Adelaide. The 100 and $200 \mathrm{~m}$ isobaths are shown. Small white triangles off Cape Nelson represent temperature logger sites; the white box west of Cape Nelson is the sample area for the NASA Giovanni tool. Source of SST data: averaged advanced very high resolution radiometer (AVHRR) SST image 5-12 March 2008 courtesy CSIRO Marine \& Atmospheric Research, Australia 
in blue whale feeding grounds elsewhere, provided insights into relationships between whales and upwelling in this region.

\section{MATERIALS AND METHODS}

Study area and zones. The study area covered $\sim 37500 \mathrm{~km}^{2}$ of continental shelf and upper slope between 134 and $143^{\circ} 30^{\prime} \mathrm{E}$, from the eastern GAB to western Bass Strait (Fig. 1). To determine whether this area could be partitioned into physiographically relevant zones, MapInfo 8.0 ${ }^{\mathrm{TM}}$ (MapInfo Corp.) was used to place 60 roughly equidistant points along the $200 \mathrm{~m}$ isobath between $133^{\circ} 50^{\prime}$ and $143^{\circ} 30^{\prime} \mathrm{E}$. For each point, distance (shelf width) and direction (shelf orientation) was calculated to the nearest land. From a cloud-free advanced very high resolution (AVHRR) sea surface temperature (SST) image taken on 25 January 2008 showing strong upwelling, an approximate mean SST was subjectively estimated along each line from $200 \mathrm{~m}$ to shore, using the SST scale bar from each image. These data were subjected to cluster analysis (ANOSIM). 'Zones' resulting from this analysis were then used for comparison of whale distribution patterns and habitat variables across the entire study area. Differences in habitat variables between zones were tested for significance using analysis of variance (ANOVA) and ranked using Bonferroni pair-wise significance tests.

Aerial surveys. A total of 69 single-platform aerial surveys were conducted between January 2002 and May 2007, with effort focused during 6 'upwelling seasons', each defined as the period between November and May. Prior aerial surveys (1998-2001) had not sighted blue whales during June-October (Gill 2002).

Aircraft were mainly high-wing twin-engine Partenavia ${ }^{\mathrm{TM}}$ flown by professional pilots. Cessna $337^{\mathrm{TM}}$ or Shrike Aero Commander ${ }^{\mathrm{TM}}$ aircraft were used occasionally. Surveys were usually flown at $\sim 240 \mathrm{~km} \mathrm{~h}^{-1}$ and at $457 \mathrm{~m}$ altitude, at which there was a $\sim 600 \mathrm{~m}$ 'blind strip' directly below the aircraft within which whales could not be detected. Bubble windows allowing downward visibility were trialled briefly in 2004, but their inherent distortion resulted in observer eye strain and their use was discontinued. All surveys between Cape Jaffa and Cape Otway followed parallel transects spaced $11.1 \mathrm{~km}$ (6 nautical miles) apart and perpendicular to overall shelf orientation, providing an area to be surveyed of $5.6 \mathrm{~km}$ (3 nautical miles) on either side of the aircraft. The study assumed equal probability of detection within this range, regardless of distance. Transects usually extended from $<1 \mathrm{~km}$ off the coast to $\sim 5 \mathrm{~km}$ offshore of the $200 \mathrm{~m}$ shelf break, as Gill (2002) found no blue whales beyond this limit. In some surveys where cetacean monitoring for hydrocar- bon seismic surveys was being conducted, some transects extended up to $30 \mathrm{~km}$ beyond the shelf break. West of Cape Jaffa, a combination of parallel and saw-tooth transects was used, as saw-tooth transects offered more rapid alongshore transit in this more remote and longitudinally extensive zone. Effort west of Cape Jaffa was concentrated on the outer shelf and upper continental slope where whales were detected during initial surveys, as the wide shelf there offered a prohibitively large area to survey.

One observer at each side of the aircraft scanned from as close to the trackline as possible out to approximately 5 to $6 \mathrm{~km}$ in conditions of Beaufort Sea State (BSS) $\leq 4$. When only 2 observers were available, 1 also recorded sightings and effort data; when 3 were available 1 was dedicated to data entry. If species identity and group size could be confirmed from the trackline, a sighting's perpendicular distance was measured from a GPS waypoint on the trackline using a Suunto PM-5 ${ }^{\mathrm{TM}}$ clinometer. However, the majority of sightings were in 'closing mode' (Hiby \& Hammond 1989), with the aircraft leaving the trackline and a GPS position obtained when circling the whale(s).

Sightings data included time, position, minimum estimate of number present, direction of movement, broad behaviour category (e.g. feeding, travelling, diving), presence of visible surface or near-surface euphausiid swarms, other species present, obvious environmental features (e.g. surface fronts), and vessels. Euphausiids were presumed to be Nyctiphanes australis, which often form daytime surface swarms but may also occur at depths where they are unavailable for sighting (O'Brien 1988). Whales were counted as belonging to the same non-mutualistic group (i.e. animals nearby but not presumed to be interacting; Connor 2000) if within approx. $500 \mathrm{~m}$ of each other, a distance that can be covered by a blue whale in $<1 \mathrm{~min}$ (P. C. Gill \& M. G. Morrice pers. obs.). BSS, glare, cloud cover, and precipitation were recorded at the start of each transect and when conditions changed during transects.

Sightings were classed 'on effort' if the aircraft was on transect and in conditions of $\leq$ BSS 4 (windspeed $\leq 30 \mathrm{~km} \mathrm{~h}^{-1}$ ) with reasonable visibility. Sightings recorded on 'transit' legs between the bases of crossshelf transects were excluded from analysis due to bathymetric bias. When the aircraft left the transect in closing mode and more animals were seen beyond the immediate vicinity of a sighting, these animals were not included as 'on effort' sightings.

The possibility of resighting whales between adjacent transects was checked by post-survey analysis of whether whales could have covered intervening distances between sighting positions at a speed of $18.5 \mathrm{~km} \mathrm{~h}^{-1}$, which exceeds the highest transit speed of 
satellite tagged blue whales recorded in the literature (14.2 $\mathrm{km} \mathrm{h}^{-1}$; Lagerquist et al. 2000). Possible resights using this transit speed were discarded.

Spatial and temporal analyses of relative abundance and distribution. Sightings data were analysed using 2 methods to assess spatial and temporal patterns of relative abundance and distribution.

The first method was density kernel estimation, considered useful for transforming point data into density estimates; Wood et al. (2000) used it to quantify foraging habitat of wide-ranging albatrosses. Density kernels are also useful measures of blue whale distribution because they present the probability of finding an individual at any location at any time, and we have used it here to graphically represent blue whale density distribution from effort-weighted aerial survey data.

Effort data were summarised by taking the start and end times for each transect and determining the total number of minutes spent flying over each cell of a predetermined $10 \times 10 \mathrm{~km}$ grid. A grid cell size of $10 \mathrm{~km}$ was chosen because at $457 \mathrm{~m}$ altitude in good sighting conditions, we could usually see $\sim 5$ to $6 \mathrm{~km}$ from each side of the aircraft (P. C. Gill unpubl. data). We assumed a constant horizontal speed along each transect so we could interpolate a new position for each minute of time along the transect, using the $\mathrm{R}^{\mathrm{TM}}$ statistical software and the Trip package. The number of original and interpolated positions within each $10 \times 10 \mathrm{~km}$ grid cell were then summed and assigned to a central node. The effort (min per grid cell) data were interpolated using the triangulation with smoothing function in VerticalMapper ${ }^{\mathrm{TM}}$ (version 2.5) (MapInfo) and plotted using MapInfo ${ }^{\mathrm{TM}}$ (version 8.0). We summarised effort data in this way for each month (November-May).

Blue whale sighting locations were then overlaid on the $10 \times 10 \mathrm{~km}$ effort grids using MapInfo ${ }^{\mathrm{TM}}$, to examine intra-seasonal differences in the locations of whales sighted per minute. We used VerticalMapper ${ }^{\mathrm{TM}}$ to extract the amount of effort (min) spent searching each sighting location. This was done for each month (November-May). We divided the number of whales sighted by the amount of time spent searching that grid cell, to determine an index of whales per minute of effort (WPME). To ensure that neither the different amounts of effort spent searching nor the different numbers of whales spotted in different months or seasons biased comparisons, the WPME data were converted to a proportion of the total WPME for each month. This gave a relative index of whales per unit effort (WPUE).

The WPUE data were plotted in ArcView ${ }^{\mathrm{TM}} 3.2$, and the animal movement extension (Hooge \& Eichenlaub 1997) was used to calculate kernel distributions for each month (November-May). WPUE data were used to weight kernel distributions, so if 2 grid cells had WPUE values of 2 and 10, respectively, it indicated that either: (1) the effort was the same but $5 \times$ more whales were sighted in the latter case, or (2) there was $5 \times$ more effort spent searching in the former case, but the same number of whales were sighted in each grid cell. We calculated the least-squares cross-validation (LSCV) for the smoothing factor for each data set, which is widely considered the most robust technique (Seaman \& Powell 1996), but for consistency in the presentation of all maps the average $H$ value (0.2) was used.

The density kernels were plotted using VerticalMapper $^{\mathrm{TM}}$ and MapInfo ${ }^{\mathrm{TM}}$ and are presented as density plots representing the entire kernel distribution, and contours representing areas within which there were 50 and $95 \%$ probabilities of detecting a whale. Because the kernel data are based on WPUE and not WPME, the plots show relative indices of whale distribution and abundance for each month Gridded survey effort and density kernels for each month are shown (see Fig. 3A).

The second method we used was encounter rate (ER), a simple numerical measure of relative abundance (whales sighted $1000 \mathrm{~km}^{-1}$ of track surveyed) to enable comparisons between zones, months and seasons (see Table 1 and Fig. 3B). As survey effort in the western zone was negligible for 3 of 6 seasons and inconsistent for the remainder, monthly variability in ER for the study area was calculated using data only from the central and eastern zones, where survey effort was relatively consistent across months and seasons and both zones were covered in a majority of surveys. Encounter rates for individual months were obtained by pooling data for each month across the 6 upwelling seasons; these are referred to as pooled monthly ERs.

Modelling of habitat data. Blue whale habitat selection models were developed to examine associations between whale distribution and selected habitat variables. A total of 407 blue whale sightings (presence points) were available for modelling. Autocorrelation was assumed to be negligible because the dataset was derived from 69 separate systematic surveys over 6 seasons. A pseudo-absence data set was generated by selecting at random 407 locations where blue whales had not been sighted in the area covered by surveys, since true absences were not available due to the unknown probability of detecting all blue whales during aerial surveys. The habitat variables listed below were considered to have potential ecological significance, and were available for each presence and pseudo-absence point.

- Depth (m)

- Distance from nearest coast $(\mathrm{km})$

- Distance from $200 \mathrm{~m}$ shelf break $(\mathrm{km})$

- Sea surface temperature $\left(\mathrm{SST}_{i}{ }^{\circ} \mathrm{C}\right)$; weekly, obtained from NOAA Pathfinder AVHRR (averaged over $4 \times 4 \mathrm{~km}$ ) 
- Sea surface chlorophyll a ( $\mathrm{chl}$ a) $\left(\mathrm{SSC}_{\mathbf{i}} \mathrm{mg} \mathrm{m}^{-3}\right)$; weekly, obtained from radiometers, NASA SeaWiFs (averaged over $1 \mathrm{~km}^{-2}$ ) and MODIS Aqua (averaged over $1 \mathrm{~km}^{-2}$ ) combined

- SST gradient $\left({ }^{\circ} \mathrm{C} \mathrm{km}{ }^{-1}\right.$, obtained from NOAA Pathfinder AVHRR)

- SSC gradient (mg km-1, obtained from SeaWiFs and MODIS Aqua combined)

Differences in scale were apparent among these variables; however, at the overall scale of the study area, these differences in scale were not regarded as consequential. The effect of bathymetry was measured by depth and distance from shelf break and coast, while SST and SSC variables were used as proxies for surface oceanography. Variables were derived using MapInfo $^{\text {TM }}$ version 8.0 and ArcGISTM 9.1. The resulting final dataset contained missing values for SST and SSC due to cloud cover, reducing the final dataset to 357 presence and 302 pseudo-absence points.

Blue whale associations with habitat characteristics were modelled with generalised GLM with logit link functions and a binomial structure assumed for the response data. Akaike's information criterion (AIC) was used to select the best explanatory model from a candidate set of models (Burnham \& Anderson 2002). The model with the lowest AIC value was taken to be the best approximating model and any model with an Aikaike difference of 0 to 2 was taken to have substantial empirical support (Burnham \& Anderson 2002). A confidence set of models was identified using an evidence ratio cutoff of 0.125 (Burnham \& Anderson 2002). As the sample size was large in relation to the number of predictor variables $(\mathrm{n}: K>40)$ the information criterion was not corrected for small sample size (e.g. $\mathrm{AIC}_{\mathrm{c}}$ ).

The importance of the individual variables contained in the best approximating model was investigated by summing the Aikaike weights of all models containing that variable. Kendall's rank correlation coefficient was used to check co-variability for pair-wise combinations of the 7 habitat variables.

The individual contribution of each habitat variable to the variation in blue whale presence was further explored using hierarchical partitioning (Quinn \& Keough 2002). This allowed calculation of the joint effects of correlated predictor variables and quantification of the total contribution of each individual predictor to explained variance.

Proxies for upwelling intensity. As further measures of habitat variability in the central zone, we developed 2 proxies for upwelling intensity to examine whether monthly changes in whale relative abundance could be related to intraseasonal changes in upwelling. First, for each month, we used mean monthly seafloor temperatures recorded at 2 or $4 \mathrm{~h}$ intervals on Stowaway
TidBit $^{\mathrm{TM}}$ temperature loggers (Onset) deployed at 3 sites near Cape Nelson between 2002 and 2007, on the assumption that seafloor temperature is lowest when upwelling is most intense (Schahinger 1987). Locations are shown in Fig. 1, and methods are described in Levings \& Gill (2010). Loggers were sometimes shifted to new nearby sites in consultation with local fishers to avoid being bottom trawled.

The second proxy for upwelling intensity was ambient SSC data for each month of the 6 upwelling seasons, obtained from NASA's Giovanni tool, which enables free online access to data from the MODISAqua $9 \mathrm{~km}$ sensor (http://reason.gsfc.nasa.gov/OPS/ Giovanni/ocean.aqua.shtml). SSC was employed as a measure of primary production for each month (pooled for all seasons), for comparison with SSC associated with whale sightings. The area sampled was a rectangle bounded to the north-west by $37^{\circ} 30^{\prime} \mathrm{S}, 139^{\circ} 45^{\prime} \mathrm{E}$, and to the south-east by $38^{\circ} 30^{\prime} \mathrm{S}, 141^{\circ} 15^{\prime} \mathrm{E}$, located to cover a significant portion of the Bonney Upwelling surface plume and some adjacent offshore waters (Fig. 1). Ambient SST data for the same area was similarly obtained from the Giovanni tool for comparison with SST associated with whale sightings. Values denoting land or cloud cover were discarded. The Giovanni tool was not available for the 2001-02 season.

\section{RESULTS}

\section{Partition of study area into zones}

Three physiographically discrete regions were identified by cluster analysis and designated as the western, central, and eastern zones (Fig. 2). Comparison of western and central zones showed strong differences based on shelf width and orientation, and mean estimated SST $(\mathrm{R}=0.935, \mathrm{p}<0.001)$, as did central and eastern zones $(\mathrm{R}=1.0, \mathrm{p}<0.001)$. Comparison of western and eastern zones was not conducted as they are not contiguous. The 3 zones are described in the following paragraphs.

The western zone has a relatively wide shelf (range: 60 to $160 \mathrm{~km}$ ) with sub-surface shelf-break upwelling recorded as far west as $\sim 136^{\circ} \mathrm{E}$ and inshore surface upwelling off Kangaroo Island (KI) and Eyre Peninsula (McClatchie et al. 2006). Surface or near-surface primary and secondary production are then thought to be advected further north-west by upwelling-favourable winds (Ward et al. 2006, McClatchie et al. 2006). Numerous cross-shelf canyons occur throughout the zone (Butler et al. 2002). The zone's western boundary was placed at the western limit of our aerial survey coverage and does not imply a physical or ecological boundary. Approximate area is $14600 \mathrm{~km}^{2}$. 
The central zone has the narrowest shelf along most of Australia's southern coast (range: 25 to $80 \mathrm{~km}$ ), and corresponds with the surface plume of the Bonney Upwelling. This narrow shelf is predicted to exhibit more intense upwelling than adjacent wider shelves (Cai \& Lennon 1993). Numerous cross-shelf canyons occur throughout the zone (Butler et al. 2002). Its western boundary $\left(138^{\circ} 55^{\prime} \mathrm{E}\right)$ occurs where the shelf widens west of Cape Jaffa and shelf orientation changes from SE-NW to E-W. Its eastern boundary occurs where the shelf widens eastward at Point Danger $\left(38^{\circ} 24^{\prime} \mathrm{S}, 141^{\circ} 39^{\prime} \mathrm{E}\right), 9.6 \mathrm{~km} \mathrm{NNE}$ of the origin of the Bonney Upwelling surface plume at Cape Nelson. During and after upwelling events, in good visibility, a distinct upwelling front was often clearly visible from the air, sometimes with evidence of internal fronts, upwelling filaments, and internal waves. Approximate area is $9800 \mathrm{~km}^{2}$.

The eastern zone is intermediate in shelf width (range: 50 to $80 \mathrm{~km}$ ) between western and central zones. Its eastern boundary was placed at Cape Otway, the entrance to Bass Strait and the eastern extent of our aerial surveys, and does not imply a physical or ecological boundary. Most previous research on upwelling focused west of Cape Nelson, leading to a perception that upwelling did not occur east of Cape Nelson (Middleton \& Bye 2007). However, Levings \& Gill (2010) used temperature loggers to confirm subsurface upwelling east of Cape Nelson, and upwelled water is often visible close inshore in AVHRR SST images along this coast (Fig. 1). Approximate area is $12900 \mathrm{~km}^{2}$.

\section{Blue whale sightings}

During 69 aerial surveys, $52567 \mathrm{~km}$ were flown on effort. Due to logistical contraints timing, number and distances of surveys flown varied considerably across the study area and between seasons. Effort in some seasons was dictated by timing and location of seismic surveys with which some survey series were associated. The more accessible central and eastern zones were covered every season, with $\sim 20 \%$ more overall effort being expended in the eastern zone due to its larger size (see Fig. 2, Table 1). Almost all effort in the western zone was concentrated in the 2003-04, 2004-05, and 2005-06 seasons, with 65\% in the 2003-04 season alone due to aerial monitoring of a seismic survey in December 2003. The earliest sightings of blue whales in any seasons were 13 November 2003 and 8 November 2004, each about 1 wk after upwelling onset, and both in the central zone.

A summary of sightings and effort for each season and zone is given in Table 1 . There were 407 sightings of blue whales totalling 525 individuals (Fig. 2). Mean group size was $1.3 \pm 0.60$. Cow-calf pairs were sighted on 10 occasions $(2.5 \%$ of sightings $)$.

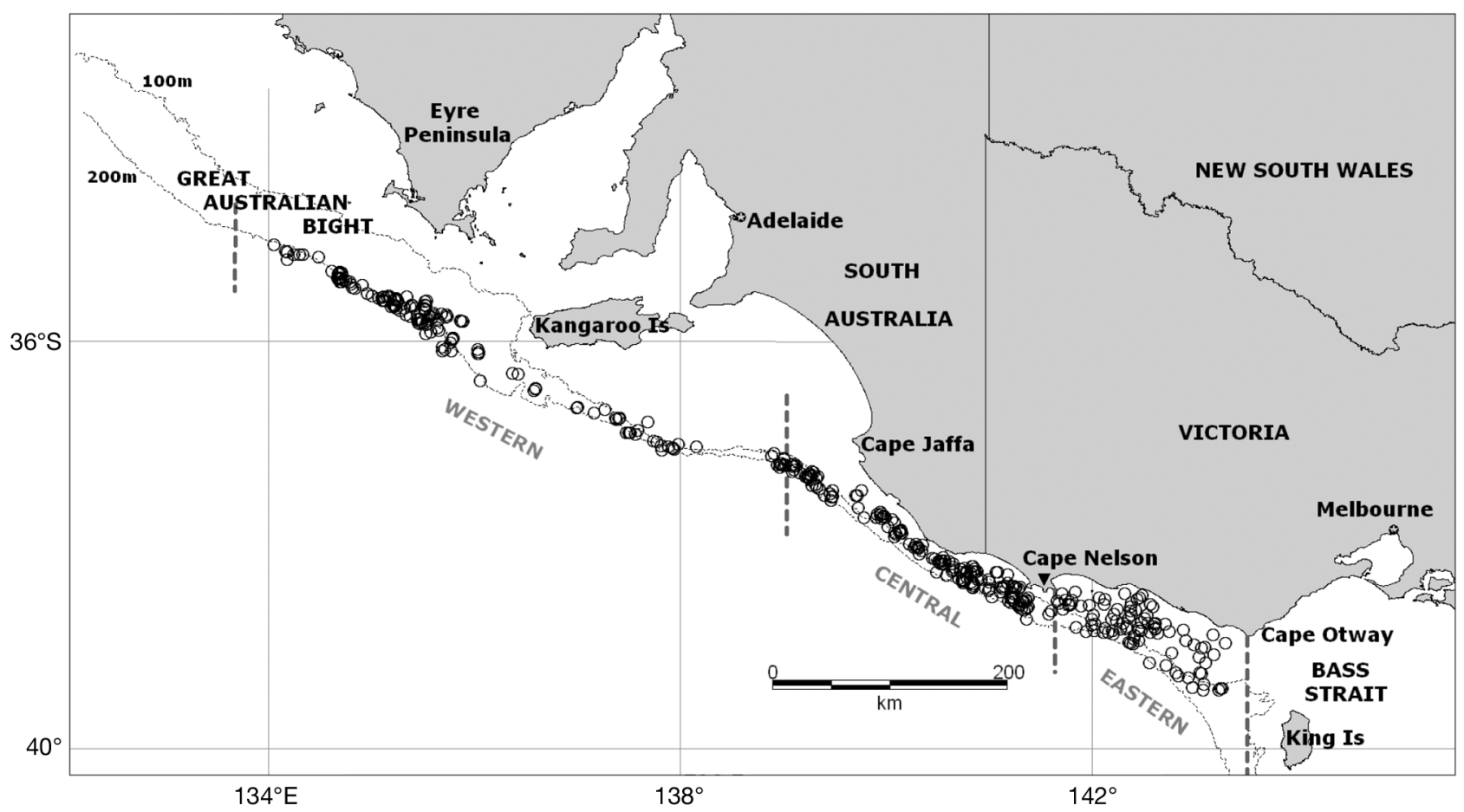

Fig. 2. Balaenoptera musculus. Distribution of blue whale sightings, 2002-07 (०). Boundaries of western, central and eastern zones are shown by dashed vertical lines 
Table 1. Summary of aerial survey effort, 2001-02 to 2006-07. Number of blue whales and encounter rates (ER) for western (W), central $(\mathrm{C})$, eastern (E) zones, and all zones combined. *Surveys often covered more than one zone

\begin{tabular}{|c|c|c|c|c|c|c|c|c|c|c|c|c|}
\hline \multirow[t]{2}{*}{ Season } & \multicolumn{3}{|c|}{ No. surveys flown } & \multicolumn{3}{|c|}{ Distance flown $(\mathrm{km})$} & \multicolumn{3}{|c|}{ No. of whales } & \multicolumn{3}{|c|}{$\begin{array}{c}\text { ER (no. whales } \\
1000 \mathrm{~km}^{-1} \text { ) }\end{array}$} \\
\hline & W & $\mathrm{C}$ & $\mathrm{E}$ & W & $\mathrm{C}$ & $\mathrm{E}$ & $\mathrm{W}$ & $\mathrm{C}$ & $\mathrm{E}$ & $\mathrm{W}$ & $\mathrm{C}$ & E \\
\hline $2001-02$ & 3 & 6 & 6 & 34 & 3085 & 3316 & 0 & 29 & 15 & 0 & 9.4 & 4.5 \\
\hline $2002-03$ & 2 & 20 & 20 & 26 & 4640 & 6906 & 0 & 46 & 22 & 0 & 9.9 & 3.2 \\
\hline 2003-04 & 8 & 11 & 9 & 5018 & 3029 & 3643 & 149 & 78 & 30 & 29.7 & 25.8 & 8.2 \\
\hline $2004-05$ & 7 & 16 & 10 & 1336 & 5525 & 4036 & 3 & 54 & 25 & 2.2 & 9.8 & 6.2 \\
\hline 2005-06 & 3 & 4 & 4 & 1382 & 2294 & 2910 & 33 & 8 & 19 & 23.9 & 3.5 & 6.5 \\
\hline $2006-07$ & 1 & 5 & 5 & 52 & 1766 & 3569 & 0 & 8 & 6 & 0 & 4.5 & 1.7 \\
\hline Total & 24 & 62 & 54 & 7848 & 20339 & 24380 & 185 & 223 & 117 & 23.6 & 11 & 4.8 \\
\hline Overall & $\longrightarrow$ & $69^{*}$ & & & 52567 & & & 525 & & & -10 & \\
\hline
\end{tabular}

Evidence of feeding was observed in 92 (23\% of) sightings. In 191 (48\% of) sightings, euphausiid surface swarms were sighted within $\sim 2 \mathrm{~km}$ of blue whales. This is the approximate radius around sightings when circling in closing mode. At times when no surface swarms were sighted (in $52 \%$ of sightings), the likely presence of submerged prey swarms was often indicated by blue whales diving steeply and resurfacing nearby, with partly open mouths and distended throat pouches. Surface swarms were sighted in all zones. In the central zone where the Bonney Upwelling surface plume was visible during many surveys, blue whales were subjectively estimated as being within $1 \mathrm{~km}$ of visible fronts in 22 (13\% of) sightings.

\section{Distribution and relative abundance patterns across zones}

\section{Density kernel estimation}

Fig. 3A-G show density kernels for each month pooled for all 6 upwelling seasons (each from November to May). Fig. 3A,B indicates an aggregation area in November and December, on the outer shelf overlapping the boundary between western and central zones. This is qualified by the fact that there was little survey coverage of this area in subsequent months. Eastward of this area, Fig. 3A,B suggests low densities of blue whales spreading eastwards during November and December as the season progressed, with blue whales restricted to the western/central zone in November, entering the eastern zone in December, and widely spread through the central and eastern zones during January, February, March, and April (Fig. 3C-F). During January-April, the distribution of density kernels changed from month to month, with no single area showing consistency in blue whale density. May showed both a marked decrease in overall whale density from April, and a contraction in distribution from the eastern zone toward the central zone (Fig. 3F,G).

In the western zone, Fig. $3 \mathrm{H}$ shows blue whales widely distributed along the outer shelf in 2 clusters south and west of KI. We acknowledge sampling bias in this zone, due to logistical constraints requiring most effort expended on the outer shelf and upper slope. For the same reason, more effort was expended west of KI, where the 100 and $200 \mathrm{~m}$ isobaths diverge widely and the outer shelf has a gentle depth gradient. Here, blue whales were found either side of the shelf break, some in very deep water. South of KI where the outer shelf is steeper due to the proximity of the 100 and $200 \mathrm{~m}$ isobaths, despite less effort, blue whale density was higher than west of KI.

\section{Encounter rates (ER)}

In the central and eastern zones, relatively consistent survey effort across all months allowed comparison of encounter rates for each month between these 2 zones (Fig. 4A). In the central zone, pooled monthly ERs for November and December were already comparable with those of January, March and April. Pooled monthly ERs peaked in February at 18.8 whales $1000 \mathrm{~km}^{-1}$, after which there was a steady decline through March and April, before a sharp decline to 0.8 whales $1000 \mathrm{~km}^{-1}$ in May.

In the eastern zone, there were no sightings in November of any season despite significant effort. Pooled monthly ER increased from 1.6 whales $1000 \mathrm{~km}^{-1}$ in December, peaked at 9.8 whales $1000 \mathrm{~km}^{-1}$ in February, dropped slightly to 8.8 whales $1000 \mathrm{~km}^{-1}$ in March, then declined sharply to a single sighting for May (0.4 whales $1000 \mathrm{~km}^{-1}$ ) (Fig. 4A). February, the month of peak ER in both central and eastern zones, coincided with the period of bottom temperature mini- 
mum (Fig. 4B) and ambient SSC maximum from the Giovanni sensor sample area (Fig. 4C), our proxies for seasonal upwelling intensity.

Both effort and ER in the western zone were extremely variable (Table 1). Six surveys between 2 and 13 December 2003 comprised $48 \%$ of total zone effort and sighted 149 whales ( $81 \%$ of zone total) at an ER of 39.3 whales $1000 \mathrm{~km}^{-1}$, while concurrent surveys in the central and eastern zones on 8 to 9 December 2003 sighted no whales (Appendix 1). A survey on 13 December 2004 covered $747 \mathrm{~km}$ for one sighting (ER: 1.3 whales $1000 \mathrm{~km}^{-1}$ ). A survey on 19 December 2005 covered $490 \mathrm{~km}$ and sighted 33 whales (ER: 67.3 whales $1000 \mathrm{~km}^{-1}$ ), while simultaneous surveys in the central and eastern zones sighted 0 whales and 1 whale, respectively (Appendix 1). There was little effort in November of any season, while surveys in April 2004 (1200 km), April 2005 (246 km), and March $2006(872 \mathrm{~km})$ comprised $30 \%$ of zone effort and recorded no sightings.

On 15 December 2003, soon after numerous sightings in the western zone, 27 blue whales were sighted in the far west of the central zone (ER: 123.3 whales $1000 \mathrm{~km}^{-1}$, the highest during the study). On 12 January 2004, 19 whales (ER: 30.6 whales $1000 \mathrm{~km}^{-1}$ ) were sighted in the central zone, and 9 whales (ER: 14.2 whales $1000 \mathrm{~km}^{-1}$ ) in the eastern zone, while on 27 February 2004, 22 blue whales were sighted in the central zone (ER: 46.4 whales $1000 \mathrm{~km}^{-1}$ ) and 21 in the eastern zone (ER: 33.2 whales $1000 \mathrm{~km}^{-1}$ ). These
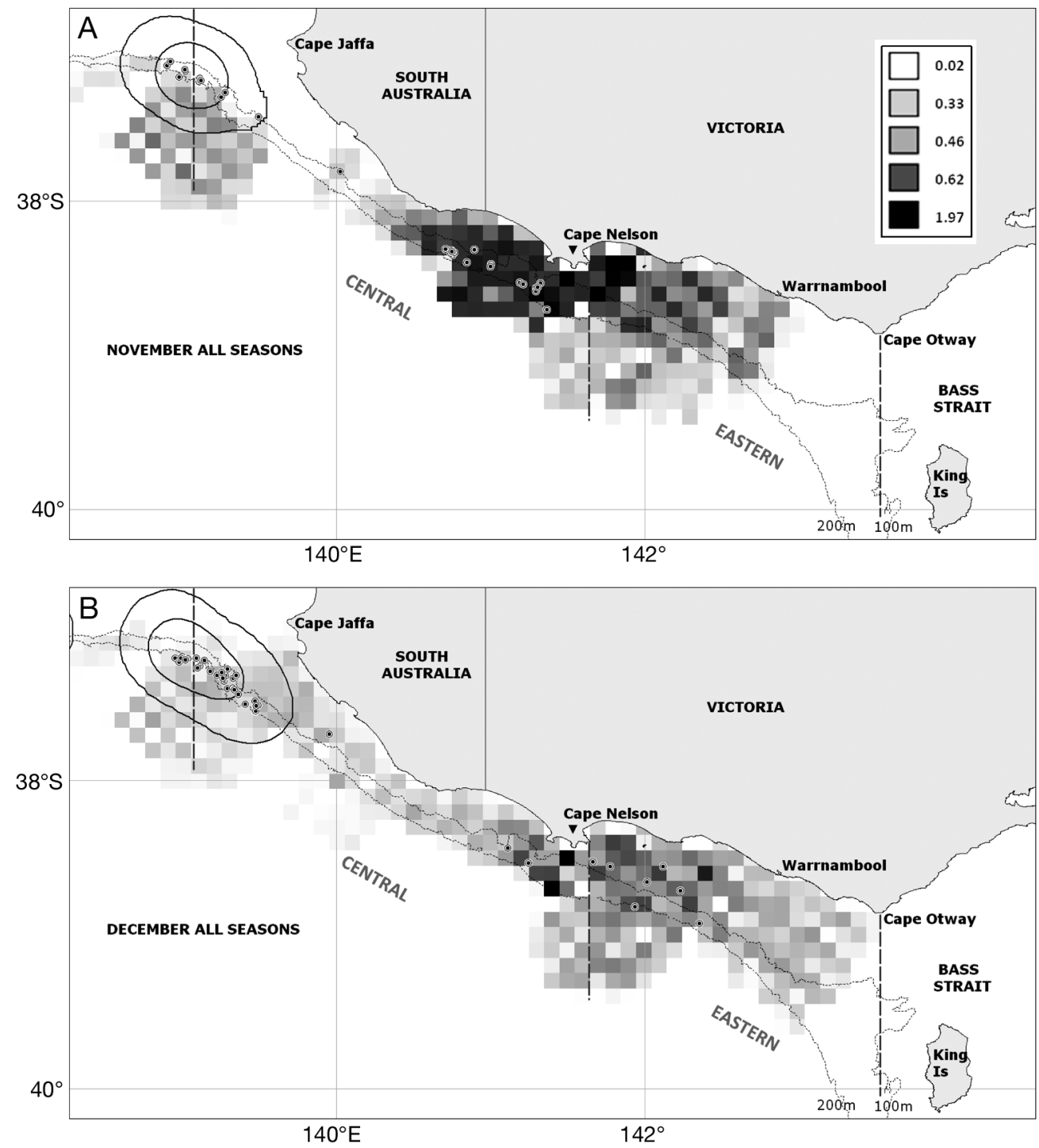

Fig. 3. Balaenoptera musculus. Blue whale sightings (॰) for (A) November, (B) December, (C) January, (D) February, (E) March, (F) April, and (G) May (pooled, all seasons), for central and eastern zones, overlaid on gridded aerial survey effort $(10 \times 10 \mathrm{~km}$ squares), represented as minutes flown per grid square (key, upper right). Thick solid lines represent 50 and $95 \%$ probability contours for blue whale distribution from density kernel analysis. Dashed lines are zone boundaries. (H) The same for December 2003, 2004, and 2005 (pooled, all seasons), western zone only. Is: Island 

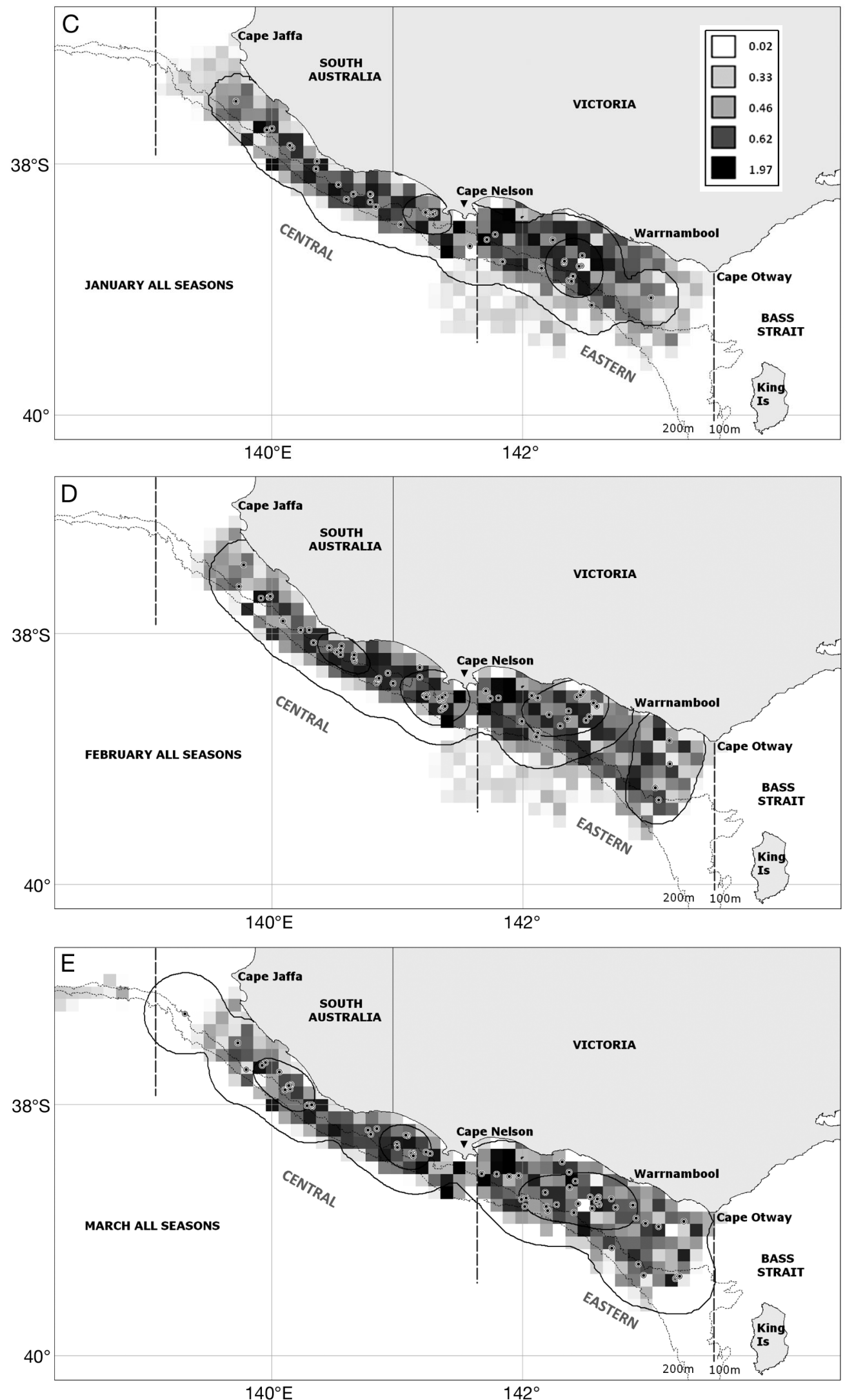

Fig. 3 (continued) 

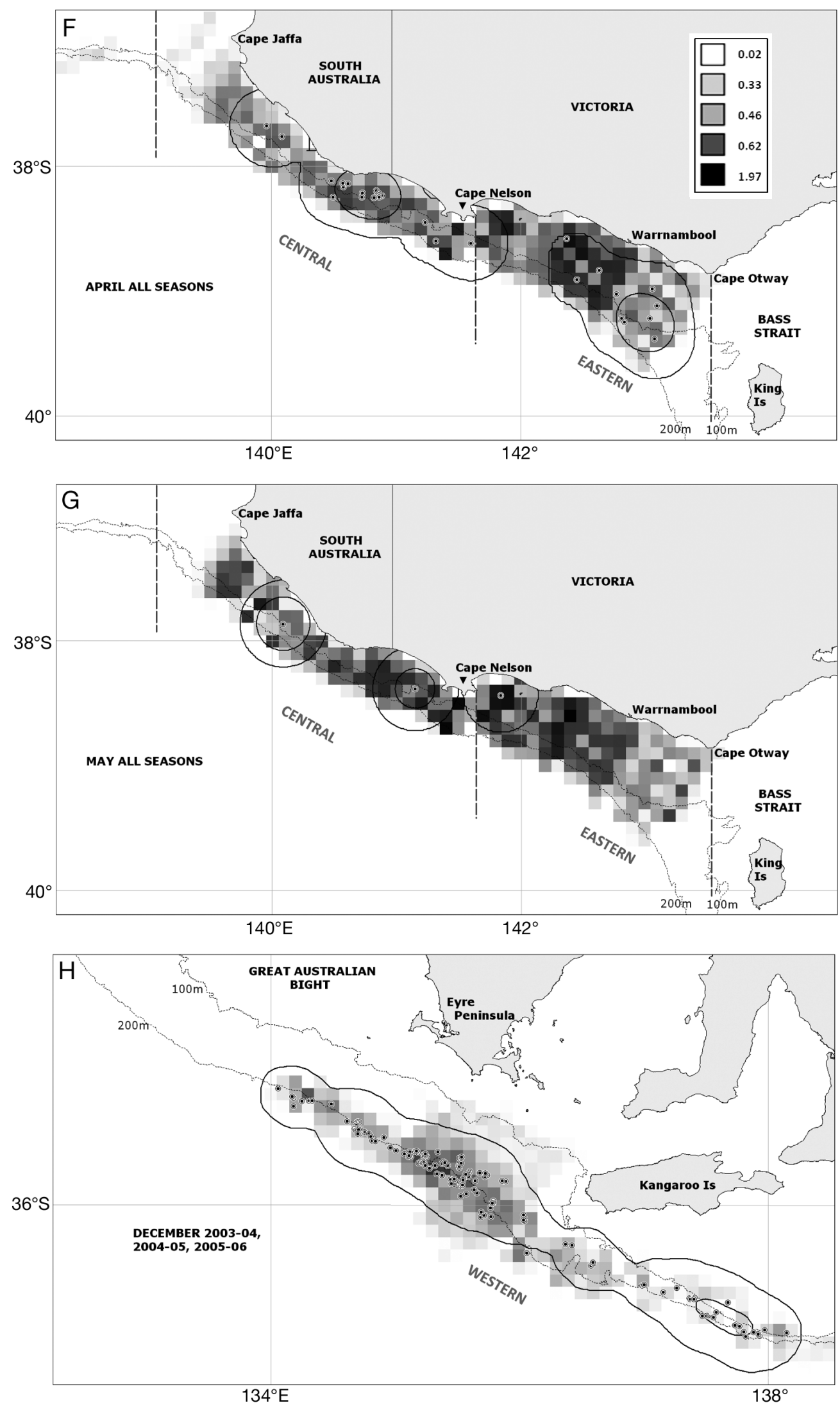

Fig. 3 (continued) 

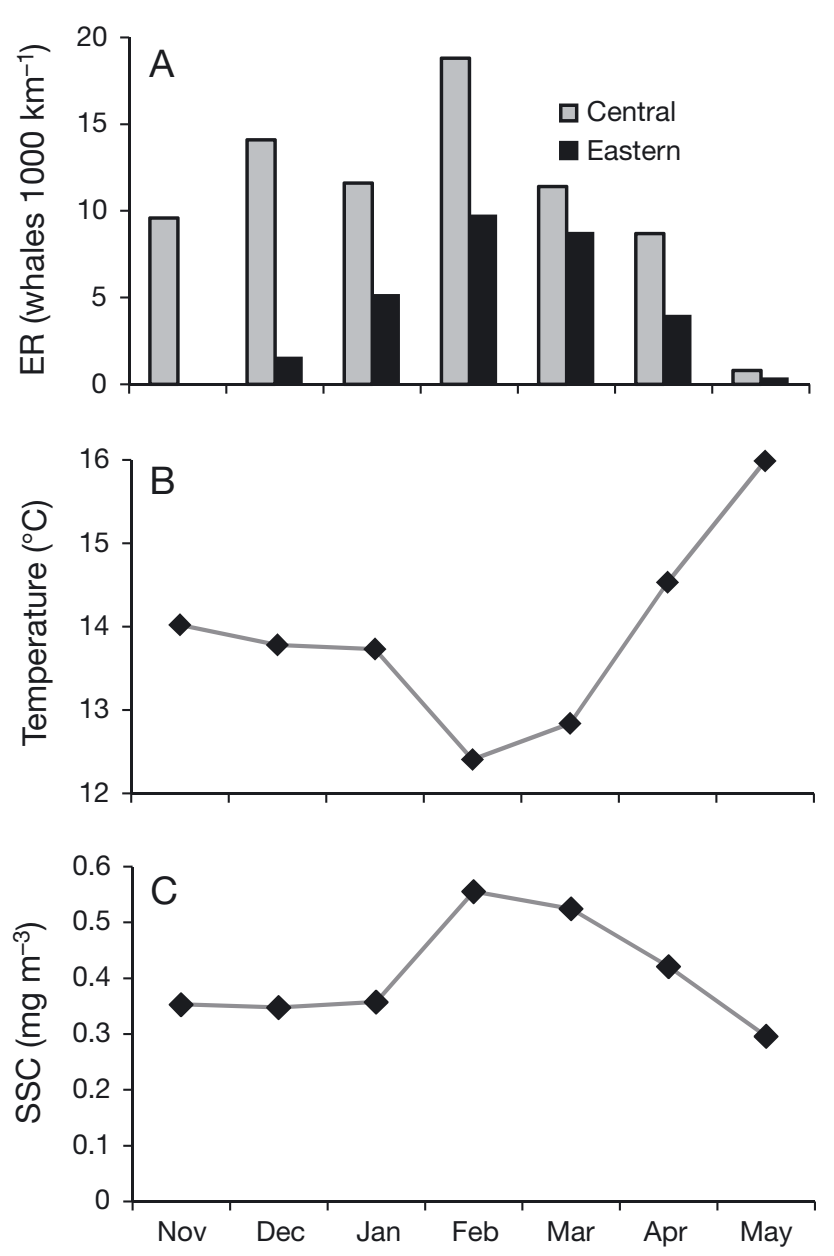

Fig. 4. Balaenoptera musculus. (A) Encounter rates (ER) by month pooled for all seasons, central and eastern zones; (B) mean monthly bottom temperature from temperature loggers, central zone; (C) mean monthly sea surface chlorophyll a (SSC) from NASA Giovanni $9 \mathrm{~km}$ tool, central zone sample area details are given to illustrate changes in whale distribution across 3 zones during that period of the 2003-04 season.

\section{Habitat modelling}

Of the 8 models contained in the confidence set $\left(w_{j} / w_{1}>0.125\right)$, the one that best explained blue whale distribution combined the 6 variables depth, SST, SSC, SSC gradient (SSCgrad), distance to shore (disshore), and distance to $200 \mathrm{~m}$ isobath (dis200) (Table 2). Two other models also had substantial support from the data with AIC differences $<2$. The first ranked model was not highly distinguished from the next few models as likely the best model for the data. The most significant variables explaining blue whale distribution were SST and SSC (tied), closely followed by depth (Table 3). Then followed distance to shore, SSC gradient, and distance to $200 \mathrm{~m}$ isobath, with SST gradient (SSTgrad) least important. Pair-wise collinearity tests amongst variables showed that most were strongly cross-correlated ( $p<0.001)$, with the exception of SST-SSTgrad $(p=0.462)$ and SSTgrad-dis200 ( $\mathrm{p}=0.026)$, making interpretation complex.

Table 3 also shows results for hierarchical partitioning, which quantifies the contribution of each habitat variable in explaining blue whale occurrence (Quinn \& Keough 2002). Using this method SST made by far the highest \% contribution ( $84.4 \%$ ) of any variable. This is consistent with modelling results in which SST scored the highest $z$ value, but here the relative contribution of SST is emphasised. Our model implies that within the range of SST associated with sightings, the likelihood of finding blue whales increases with increasing SST.

Table 2. Results of Akaike's information criterion (AIC)-based model selection for associations between blue whale Balaenoptera musculus.distribution and habitat variables. Models included in the plausible set $\left(w_{j} / w_{1}<0.125\right)$ plus one (in italics) are listed. Models with substantial empirical support are indicated by AIC $<2 . K=$ no. of variables in the model; $\Delta$ AIC $=$ Akaike difference; $w_{i}=$ Akaike weight; $w_{j} / w_{1}=$ ratio for confidence set of models from likelihood based inference. Variables include: depth; disshore $=$ distance to shore; dis200 = distance to $200 \mathrm{~m}$ isobath; $\mathrm{SST}=$ sea surface temperature; $\mathrm{SSC}=$ sea surface chlorophyll $a_{;}$ SSTgrad = SST gradient; SSCgrad = SSC gradient

\begin{tabular}{|lccccc|}
\hline Model & $K$ & AIC & $\Delta$ AIC & $W_{i}$ & $W_{j} / W_{1}>0.125$ \\
\hline Depth + SST + SSC + SSCgrad + disshore + dis200 & 6 & 638.9 & 0 & 0.3192 & 1 \\
Depth + SST + SSC + SSCgrad + disshore & 5 & 640.5 & 1.6 & 0.1434 & 0.4493 \\
Depth + SST + SSTgrad + SSC + SSCgrad + disshore + dis200 & 7 & 640.9 & 1.99 & 0.118 & 0.3697 \\
Depth + SST + SSC + disshore + dis200 & 5 & 641.4 & 2.42 & 0.0952 & 0.2982 \\
Depth + SST + SSTgrad + SSC + disshore + dis200 & 6 & 642 & 3.01 & 0.0709 & 0.222 \\
Depth + SST + SSTgrad + SSC + SSCgrad + disshore & 6 & 642.2 & 3.21 & 0.0641 & 0.2009 \\
Depth + SST + SSC + SSCgrad + dis200 & 5 & 642.5 & 3.6 & 0.0528 & 0.1653 \\
Depth + SST + SSTgrad + SSC + disshore & 5 & 642.9 & 3.99 & 0.0434 & 0.136 \\
Depth + SST + SSC + dis200 & 4 & 644 & 5.01 & 0.0261 & 0.0817 \\
\hline
\end{tabular}


Table 3. The relative importance of 7 habitat variables in explaining blue whale Balaenoptera musculus distribution in the present study, ascertained by summing Akaike weights $\left(w_{i}\right)$ across the candidate model set. I: \% likelihood, ascertained by hierarchical partitioning, that each habitat variable contributes to variation in blue whale presence. Variables as defined in Table 2

\begin{tabular}{|lccc|}
\hline Variable & Sum $w_{i}$ & $\begin{array}{c}\text { Importance } \\
\text { rank }\end{array}$ & I \\
\hline SST & 1 & 1 & 84.4 \\
SSC & 1 & 2 & 4.1 \\
Depth & 0.991 & 3 & 3.6 \\
Disshore & 0.879 & 4 & 2.8 \\
SSCgrad & 0.7286 & 5 & 1.9 \\
Dis200 & 0.7222 & 6 & 1.9 \\
SSTgrad & 0.3336 & 7 & 1.3 \\
\hline
\end{tabular}

\section{Habitat differences between zones}

When habitat variable data for blue whale sightings were pooled across all seasons, there were significant differences in ANOVA between at least 2 zones for all variables. These and relative ranking based on pairwise significance tests are shown in Table 4.

\section{SST}

Hierarchical partitioning showed that SST is overwhelmingly the most significant habitat variable explaining the presence of blue whales (Table 3), yet there was significant SST variability between all zones at sightings locations (Table 4). Of the 3 zones, the central zone offered the most direct insights into SST due to the Bonney Upwelling surface plume. SST values for sightings there were significantly lower than in the eastern or western zones, and SST gradients were significantly stronger than in eastern or western zones. Schahinger (1987) used the $17^{\circ} \mathrm{C}$ isotherm to delimit the outer edge of recently upwelled water of the Bonney Upwelling surface plume. SST was $\leq 17^{\circ} \mathrm{C}$ for $62 \%$ of sightings in the central zone for which SST was available, indicating a close relationship of whales with recently upwelled water, although blue whales were never sighted in the coldest inshore upwelling centres when sightings were routinely plotted against SST images. For all months but November mean monthly SST selected by whales in the central zone was about 0.5 to $1^{\circ} \mathrm{C}$ cooler than mean monthly ambient $\mathrm{SST}$ (mean $\pm \mathrm{SD}$ : $16.9 \pm 0.91^{\circ} \mathrm{C}$; range: 14.2 to $19.7^{\circ} \mathrm{C}$ ) obtained from the Giovanni tool in the sample area (Fig. 5).

In the eastern zone SST was $\leq 17^{\circ} \mathrm{C}$ in $45 \%$ of sightings, while in the western zone SST was $\leq 17^{\circ} \mathrm{C}$ in $11 \%$ of sightings. When the 2 clusters of western zone sight-

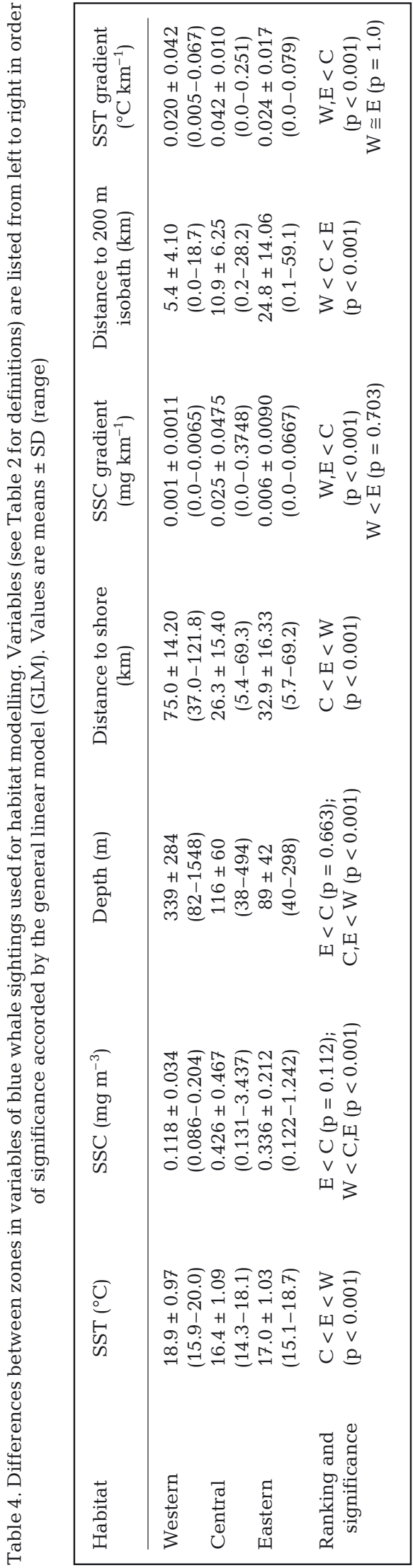




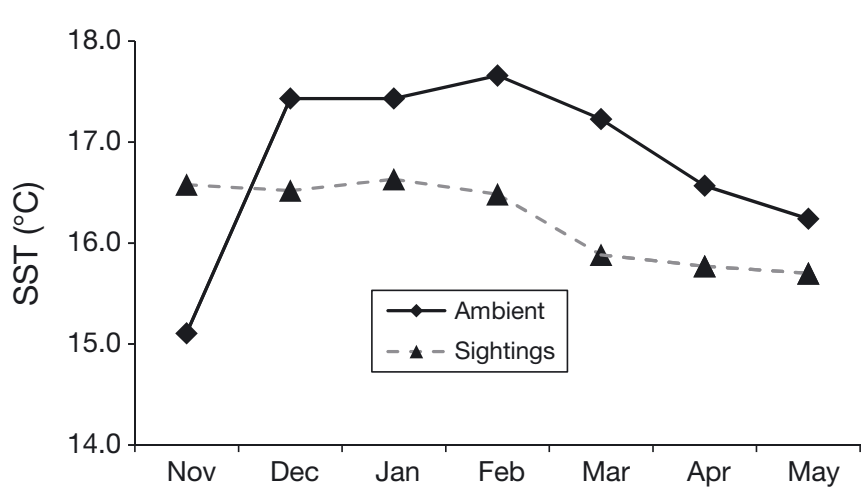

Fig. 5. Sea surface temperature (SST) for sightings of blue whale Balaenoptera musculus, and ambient SST from the Giovanni sensor for the central zone sample area, by month (pooled seasons)

ings west and south of Kangaroo Island were analysed separately, SST values west of Kangaroo Island were significantly higher (mean $\pm \mathrm{SD}: 19.2 \pm 0.77^{\circ} \mathrm{C}$ ) than to its south $\left(18.0 \pm 1.02^{\circ} \mathrm{C} ; \mathrm{p}<0.001\right)$.

\section{$\mathrm{SSC}$}

The highest SSC values occurred in the central zone, with high variability occurring in both central and eastern zones. Blue whales were never sighted in inshore upwelling centres where SSC was very low in SeaWiFs images. For all months except November, blue whales in the central zone selected higher mean SSC than mean ambient SSC (mean \pm SD: $0.186 \mathrm{mg}$ $\mathrm{m}^{-3} \pm 0.062$; range: 0.078 to $0.484 \mathrm{mg} \mathrm{m}^{-3}$ ) from the Giovanni sensor (Fig. 6).

Mean SSC for sightings in the eastern zone was lower (though not significantly) than in the central zone. The western zone exhibited significantly lower SSC than the central or eastern zones, and when the 2 clusters of sightings west and south of Kangaroo Island were analysed separately, $\mathrm{SSC}$ values to the west were significantly lower (mean $\pm \mathrm{SD}$ : $0.101 \pm 0.014 \mathrm{mg} \mathrm{m}^{-3}$ ) than to the south $\left(0.171 \pm 0.022 \mathrm{mg} \mathrm{m}^{-3} ; \mathrm{p}<\right.$ 0.001).

\section{Depth}

Depth frequency distribution for sightings in all zones is shown in Fig. 7. Depth means and ranges are given in Table 4 . Mean depth was not significantly different between central and eastern zones, and for

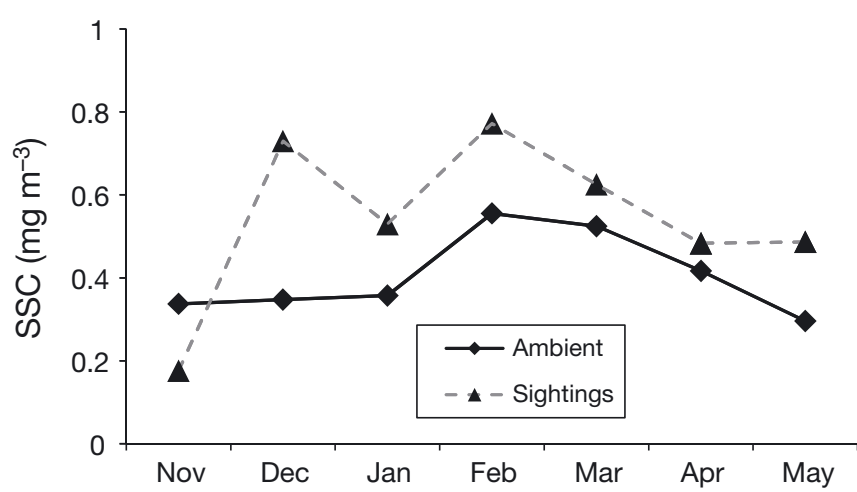

Fig. 6. Sea surface chlorophyll a (SSC) for sightings of blue whale Balaenoptera musculus, and ambient SSC from the Giovanni sensor by month (pooled seasons), for the central zone sample area

the most part they shared a similar range, with $80 \%$ of sightings in the central zone and $78 \%$ of sightings in the eastern zone between 50 and $150 \mathrm{~m}$. The deepest sightings in the central zone were near the western zone boundary; this may represent a transition from a shallower, cross-shelf distribution to a deeper, outershelf distribution.

In the western zone overall, sightings were in deeper water. Our surveys focused on the outer shelf so may have missed whales in depths $<50 \mathrm{~m}$. Only $32 \%$ of sightings were in the 50 to $150 \mathrm{~m}$ depth range across the western zone, with the remainder in deeper water (151 to $1548 \mathrm{~m}$ ). When the 2 clusters of sightings west and south of KI (Fig. 3H) were analysed separately, mean sightings depth south of KI was $150 \mathrm{~m}( \pm 67 \mathrm{SD})$, significantly shallower $(p<0.001)$ than west of KI where mean sightings depth was $389 \mathrm{~m}( \pm 299 \mathrm{SD})$.

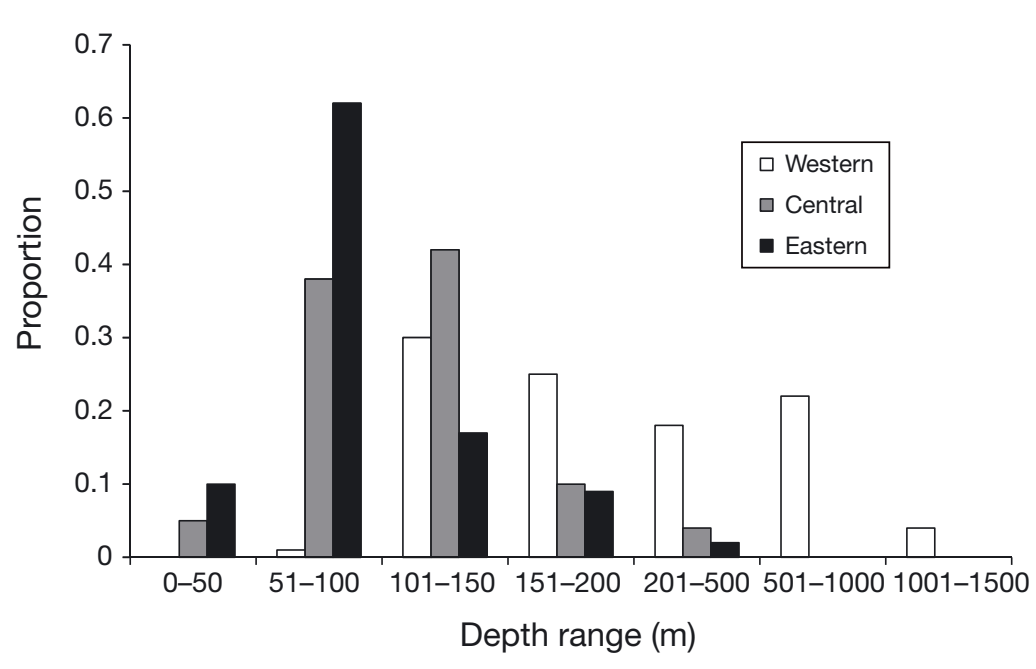

Fig. 7. Balaenoptera musculus. Sightings depth distribution in the 3 zones. Note the change in horizontal scale above $200 \mathrm{~m}$ to accommodate the extended depth range in the western zone 
South of KI $22 \%$ of sightings were in depths $>200 \mathrm{~m}$, while west of KI $50 \%$ of sightings were in depths $>200 \mathrm{~m}$.

\section{Distance to shore and to shelf break}

The mean distance from sightings to shore was least in the central zone, greater in the eastern zone and greatest in the western zone, corresponding to the relative shelf widths in the 3 zones.

The mean distance from sightings to the $200 \mathrm{~m}$ isobath decreased from east to west. Using $5 \mathrm{~km}$ as an arbitrary measure of proximity, in the eastern zone, $10 \%$ of sightings were within $5 \mathrm{~km}$ of the $200 \mathrm{~m}$ isobath; in the central zone $22 \%$ of sightings were within $5 \mathrm{~km}$; and in the western zone $62 \%$ of sightings were within $5 \mathrm{~km}$. Overall, distance to $200 \mathrm{~m}$ isobath ranked below distance to shore in our model.

\section{DISCUSSION}

\section{Habitat preferences of blue whales in the study region}

SST was identified as by far the most important habitat variable in our model. The model indicated an increasing probability of sighting blue whales with increasing SST, suggesting that for the area and dataset modelled, blue whales selected relatively warmer waters. The whales were found not in the coldest upwelling centres of the Bonney Upwelling but in warmer adjacent waters. This is not surprising; upwelling centres in the Bonney Upwelling, as in upwelling systems elsewhere (e.g. Wieters et al. 2003, Broitman \& Kinlan 2006), exhibit not only low SST but low chl a concentrations (Lewis 1981). Thus primary and consequent secondary production are likely to be low in these cold centres.

There is a seeming contradiction between the model's finding that whales selected relatively warmer SST at the scale of the study, and 'Giovanni' mean monthly SST data for the central zone showing that whales selected SST $\sim 1^{\circ} \mathrm{C}$ cooler than ambient SST (Fig. 5). We interpret this as an indication that whales selected neither the coldest nor the warmest SST available in the area sampled. The distribution of both the pseudo-absence points used in the model, and the Giovanni tool sample area, covered from cold inshore upwelling centres where whales were not sighted, through the cool water of the upwelling plume itself, into warmer waters offshore of the upwelling plume (Fig. 1). Nearly two-thirds of sightings in the central zone were in $\mathrm{SST} \leq 17^{\circ} \mathrm{C}$, defined by Schahinger (1987) as recently upwelled. The positive relationship between whale occurrence and SST indicated only that whales tended to be found in relatively warmer water across the specific range of SST values for the locations (presences and absences) included in the model. A positive relationship with SST at the scale of the upwelling system does not preclude cold water surface plumes being a significant predictor of blue whale distribution over wider oceanic domains. From an ecological perspective, SST is likely to be a significant predictor on a broad scale because of its relationship to upwelled nutrients and the effect on primary and secondary production (Grémillet et al. 2008, Whitehead et al. 2010).

Elsewhere, SST appears to vary in importance as a predictor of rorqual foraging habitat. Moore et al. (2002) and Irvine \& Mate (2007) found low or decreasing SST to be a consistent indicator of blue whale habitat in the northwest Pacific Ocean, while Stafford et al. (2009) concluded that SST was the best predictor of blue (Balaenoptera musculus) and fin (B. physalus) whale call detections across the north Pacific. Further south around California's Channel Islands, blue whales were associated with cold $\left(<16^{\circ} \mathrm{C}\right)$, well-mixed, productive water (Fiedler et al. 1998).

The inherently complex nature of upwelling systems and the interaction of variables within them makes the interpretation of the role of any one particular environmental variable, such as SST, less than straightforward. Correlation between SST (or any other variable) and whale presence does not necessarily imply a causal relationship, and given the function of the Bonney Upwelling as a foraging area, variability in blue whale responses to SST is likely a result of the complex and dynamic interactions of SST with prey availability. The other highly significant variables in our modeling indicated that SST alone does not accurately predict blue whale distribution.

Prior to hierarchical partitioning analysis, SSC was of equal importance to SST in explaining blue whale distribution, closely followed by depth (Table 3), with all 3 variables highly cross-correlated. Smith et al. (1986) proposed SSC as a habitat descriptor for blue whales in the California Current, with blue whales in that region showing a preference for SSC values between 3.8 and $4.5 \mathrm{mg} \mathrm{m}^{-3}$, comparable to the highest values for sightings in our central zone $\left(3.4 \mathrm{mg} \mathrm{m}^{-3}\right)$. On a larger scale, blue whales were tracked by passive acoustic arrays as they followed the seasonal SSC bloom north along the Pacific coast of North America (Burtenshaw et al. 2004).

SST gradient in the present study, while significantly more pronounced in the central zone due to the Bonney Upwelling surface plume, was among the lowest ranked habitat variables in the GLM. The relationship 
between whales and fronts has been studied at a range of spatial scales, raising potential difficulties when comparing results from studies conducted at different scales. In the eastern tropical Pacific, blue whales were associated with 'subtle' SST gradients $\left(0.01\right.$ to $0.1^{\circ} \mathrm{C}$ $\mathrm{km}^{-1}$; Etnoyer et al. 2006) of similar magnitude to those detected by our own analysis $\left(0.0\right.$ to $0.251^{\circ} \mathrm{C} \mathrm{km}^{-1}$ in our central zone). SST fronts were considered important in explaining blue whale distribution elsewhere (Moore et al. 2002, Etnoyer et al. 2004, 2006, DoniolValcroze et al. 2007, Irvine \& Mate 2007). In the Gulf of St. Lawrence, blue whales occurred closer to SST fronts than fin, humpback (Megaptera novaeangliae) or minke (Balaenoptera acutorostrata) whales (DoniolValcroze et al. 2007), while Etnoyer et al. (2006) suggested that foraging blue whales are sensitive to relatively subtle SST fronts. Proximity of sightings to surface fronts in the Bonney Upwelling will be tested in future predictive modelling.

SSC gradient also ranked relatively low as a variable in our model (although somewhat higher than SST gradient), and Moore et al. (2002) considered that SSC fronts were not a good indicator of blue whale habitat in the northwest Pacific. References in the literature to SSC fronts as predictors of rorqual habitat are scarce.

Doniol-Valcroze et al. (2007) pointed out that if a surface gradient is measured at the exact position of a sighting it may appear insignificant, whereas there may be a lag between a biologically significant surface feature e.g. a front, and a sighting. This was emphasised by Grémillet et al. (2008) who found spatial mismatch between trophic levels in the Benguela Upwelling, and cautioned about the limitations of using remote sensed patterns of primary productivity to interpret the foraging behaviour of marine top predators.'

While satellite remote sensing can detect surface features it has limited ability to detect sub-surface gradients, and without in situ measurement, extrapolation from surface to sub-surface processes is difficult. Cooler upwelled water is known to underlie warmer surface water in all 3 zones in our study area (Schahinger 1987, McClatchie et al. 2006, Levings \& Gill 2010), and whales may often have been in close vertical proximity to sub-surface gradients that can aggregate primary and secondary production (Friedlaender et al. 2006, van Ruth 2009). Detecting relationships between blue whale distribution and surface fronts may be difficult due to sub-surface vertical structure, temporal lag, and gradient subtleties mentioned above.

With regard to depth, blue whale feeding grounds in the southern hemisphere are usually associated with deep pelagic waters, exceptions being regions with narrow continental shelves such as the Bonney
Upwelling (Branch et al. 2007), suitable habitat for neritic euphausiids such as Nyctiphanes australis (Blackburn 1980). In the central and eastern zones of our study area combined, $93 \%$ of blue whale sightings occurred in depths $\leq 200 \mathrm{~m}$. In the central zone this depth range is often occupied by the surface upwelling plume, so depth may be a secondary consequence of the degree of displacement of the upwelling front from the coast. In the eastern zone, sightings were widely spread across the broader shelf (Fig. 2), likely due to widely dispersed sub-surface upwelling.

In the western zone, only $50 \%$ of sightings occurred in depths $\leq 200 \mathrm{~m}$, with many sightings occurring in upper slope waters as deep as $1548 \mathrm{~m}$. In the western zone west of KI, blue whale and euphausiid distribution may result from the presence of nutrient-rich water advected from the 'Kangaroo Island pool' (McClatchie et al. 2006). This water may drift either inshore or offshore of the shelf break depending on wind direction, explaining the depth range of sightings (82 to $1548 \mathrm{~m}$ ) and the high proportion (50\%) of all sightings west of KI in depths $>200 \mathrm{~m}$. However, the presence of complex cross-shelf canyons in this area, similar to those linked to upwelling on the Bonney Coast (Butler et al. 2002), and reports of blue whale sightings westward almost to $131^{\circ} \mathrm{E}$ (K. White pers. comm.) leave open the possibility of upwelling west of the 'cold pool', and the extension of blue whale foraging habitat further west than we have shown here.

\section{Relationship of habitat to primary and secondary production}

A key determinant of blue whale distribution in this upwelling region is likely to be the distribution of their euphausiid prey Nyctiphanes australis, the ecology of which is little known in this upwelling system. While quantitative prey data would be of prime importance as a habitat variable at a range of scales (e.g. Fiedler et al. 1998, Friedlaender et al. 2006), the only prey data available in our study were those from aerial observations at the ocean surface, so we can only draw inferences from other work that describes relationships between euphausiids and upwelling habitat.

Surface swarms (presumably Nyctiphanes australis, which invariably comprised surface swarms sampled from vessels during other work) were regularly recorded during our aerial surveys in all areas where blue whales were sighted, with many observations of surface feeding recorded. Surface swarms were observed in a range of depths between 20 and $1500 \mathrm{~m}$, although rarely exceeding $200 \mathrm{~m}$. But for $52 \%$ of sightings no krill was visible at the surface, suggesting that blue whales were either in transit, or feeding deeper in 
the water column, as occurs elsewhere (Croll et al. 2005, Rennie et al. 2009). Hydroacoustic surveys in shelf waters of our central zone have found $N$. australis swarms at any depth, with changes in distribution and density occurring over hours (P. C. Gill and M. G. Morrice unpubl. data). While we can only speculate about depths at which feeding occurred during our surveys, on many occasions we recorded blue whales surfacing slowly from below the limit of visibility with distended throat pouches and partially open mouths.

While blue whale sightings in our study were associated with SST as high as $20^{\circ} \mathrm{C}$, the optimal temperature range for Nyctiphanes australis is 12 to $18^{\circ} \mathrm{C}$ (Blackburn 1980), and vertical migration by Nyctiphanes spp. is not generally constrained by thermoclines (Williams \& Fragopolou 1985, Lavaniegos 1996). In the Kahurangi Point-Cape Farewell Upwelling, New Zealand, $N$. australis were found in a range of depths and were thought to position themselves on the shelf by vertical migration into water strata that were either upwelling inshore, or advecting offshore (Bradford \& Chapman 1988, Bradford-Grieve et al. 1993). Such behaviour may address the imperative to maintain depths at which chl a or other productivity maxima occur.

Chl a maxima may occur at an upwelling front, or along the thermocline at varying depths, horizontally displaced from surface fronts (Pitcher et al. 1998). In the Bonney Upwelling, chl a maxima were found at $50 \mathrm{~m}$ depth, offshore of the surface plume (Kämpf et al. 2004), and in the Perth Canyon blue whale feeding area, at 80 to $90 \mathrm{~m}$ where upwelling occurs below the oligotrophic Leeuwin Current (Rennie et al. 2009). In our western zone, high primary productivity was found in upwelled water below the surface mixed layer (van Ruth 2009). In the eastern zone, chl a maxima may also be sub-surface. In upwelling systems elsewhere, peak primary production is displaced 'downstream' and offshore from upwelling centres by wind-forced alongshore advection of upwelled water over distances of 15 to $30 \mathrm{~km}$ (Wieters et al. 2003, Broitman \& Kinlan 2006), comparable to Schahinger's (1987) estimate of $20 \mathrm{~km}$ as the scale of upwelling displacement in the Bonney Upwelling. In the Kahurangi Point-Cape Farewell Upwelling, Nyctiphanes australis were scarce near the upwelling source and most abundant at the distal end of the upwelling plume (Bradford \& Chapman 1988). In our surveys, euphausiid surface swarms were never sighted in coastal upwelling centres.

Basking sharks Cetorhinus maximus in the English Channel foraged along thermal fronts and were able to locate rich zooplankton patches above a threshold density (Sims \& Quayle 1998). It is probable that fronts associated with the Bonney Upwelling surface plume also served to aggregate prey above threshold densi- ties (Piatt \& Methven 1992), thus attracting blue whales. However, while surface upwelling in the central zone has simplified our ability to observe frontal phenomena that may aggregate prey, it is essentially the shoaling of poorly understood sub-surface processes, undetectable in our study, that are likely to prevail in the western (van Ruth 2009) and eastern zones, and to an unknown degree in the central zone as well.

There is also the likelihood of spatial mismatch (Grémillet et al. 2008) between trophic levels, i.e. primary and secondary production. While knowledge of Nyctiphanes australis' diet in our study area is rudimentary, Ritz et al. (1990) calculated that only $25 \%$ of its carbon requirements off southern Tasmania were obtained from phytoplankton, suggesting significant predation on smaller zooplankton. This may add another trophic level into the food chain topped by blue whales, which could contribute to further physical displacement of sightings from areas of chl a maxima. Swarming behaviour driven by reproductive or energy conservation requirements could also uncouple aggregation from areas of peak biological production (Ritz 1994).

\section{Effectiveness of the study zones}

The discrimination of the large survey area into 3 zones was validated by significant differences between them for all habitat variables (Table 3), and the use of zones has improved our ability to describe events and potential habitat types across the study area. This variability between zones has highlighted how heterogeneous habitat can be even within a relatively restricted region, and illustrates the difficulties of extrapolating results from one area to another. Some variables (i.e. SST, SSC, SSTgrad, SSCgrad) set apart the central zone and its Bonney Upwelling surface plume from zones with limited surface upwelling. There were also some similarities between zones, e.g. depth and SSC between the central and eastern zones, SSTgrad and SSCgrad between the eastern and western zones (Table 4), reflecting the nature of upwelling in these zones.

While for logistical reasons we treated the western zone as a single entity, our analysis has shown 2 distinct areas south and west of KI, that might be termed 'sub-zones'. The 2 clusters of sightings in these subzones (Fig. 3H) showed significant differences in SST, $\mathrm{SSC}$, and depth. Higher relative abundance of whales occurred south of KI, where likely shelf-break upwelling on a steep, narrow outer shelf produces conditions similar (low SST, high SSC, mean depth of $150 \mathrm{~m}$ ) to the central zone. The area west of KI, likely influenced by advection from the upwelled 'cold pool', had the highest SST, the lowest SSC, and the greatest mean depth (389 $\mathrm{m})$ in the study area. 


\section{Within-season longitudinal movement between zones}

Blue whale distribution and relative abundance were fluid throughout the study region during all months of the feeding season, with general agreement between ER and kernel data. The kernel maps (Fig. 3) were based on WPUE data so that we could objectively compare between years, months, and regions. Our method of mapping the kernel distribution may have biased the apparent ecological importance of some of the regions. This potential bias is apparent in Fig. 3A,B, in which some whale sightings were not encompassed by kernels, because these sightings occurred in regions with relatively high effort, whereas the sightings that were encompassed by kernels occurred in regions with relatively low effort. These maps accurately reflect the WPUE in each region, but had we invested further search effort west of $140^{\circ} \mathrm{E}$ (and seen few whales there), the kernels may have been more evenly spread.

The overall pattern of seasonal distribution implied that blue whales start foraging from the west early in the upwelling season, spread eastward through the central and eastern zones until April, then possibly contract toward the central zone prior to departure for wintering grounds in April or May.

The western zone was clearly of high importance during December of 2003 and 2005, when abundant euphausiid surface swarms and relatively high blue whale densities were evident along the outer shelf. At times of high relative abundance in the western zone, relative abundance was low in the central and eastern zones, suggesting that at those times the western zone was the principal blue whale feeding ground off southern Australia. Yet during the December 2004 survey, only one blue whale was found during an extensive survey of the western zone. We cannot explain this extreme variability in blue whale occurrence in the eastern GAB, which is consistent with van Ruth's (2009) finding of highly variable primary productivity there.

The vicinity of the western/central zone boundary appeared highly productive in November and December, but we can only speculate whether this was so during later months when there was little survey coverage of this area. Shelf orientation here (moving from east to west) changes from SE-NW to E-W, creating an 'elbow' within which upwelling may intensify locally. West of this 'elbow' there is a probable hiatus in shelfbreak upwelling, until the shelf resumes its SE-NW orientation south of the eastern tip of Kangaroo Island. Only 1 whale sighting occurred in this likely 'upwelling hiatus' area (Fig. 3H).

Of the 3 zones, the central appeared the most consistently utilised by blue whales. Relative abundance was comparable during November-January, followed by a peak during February that coincided with the seafloor temperature minimum and the ambient SSC maximum (Fig. 4). Nieblas et al. (2009) found that upwellingfavourable winds are strongest and most persistent during January-February. This accords with Croll et al.'s (2005) finding of peak euphausiid densities in Monterey Bay 3 to 4 mo after the onset of upwelling. After February there was a decline in relative abundance, suggesting gradual movement out of this zone from March to May.

In the eastern zone, the pattern of pooled monthly ER showed an increase from December to a peak in February, indicating movement into this zone as upwelling intensified. This was followed by a decline in ER through April and May suggesting movement out again. As in the central zone, density 'hot spots' changed from month to month, with February showing the most inshore distribution. The absence of blue whale sightings in the eastern zone in November is puzzling, and suggests a delayed arrival into that zone. A possible explanation was provided by Levings \& Gill (2010), who compared bottom-moored temperature logger data between $139^{\circ} 17^{\prime} \mathrm{E}$ (near the western/central zone boundary) and $142^{\circ} 54^{\prime} \mathrm{E}$ (near the southeastern extremity of the eastern zone) during the 2005-06 season. The general pattern of temperature change was similar at both sites, but during a major upwelling event at the end of 2005, the decrease in bottom temperature at the eastern site occurred $16 \mathrm{~d}$ behind the western site. This indicated a lag in upwelling and associated biological production in the eastern zone, perhaps due to the wider shelf, that could have contributed to the delayed arrival of blue whales in the eastern zone until these processes were more advanced in December.

Foraging rorquals move often to exploit changing prey dynamics. We have limited movement and residency data for individual whales in our study area, but photo-identification (Calambokidis et al. 1990, 2009) and satellite-based telemetry (Mate et al. 1999, Bailey et al. 2009) demonstrated within-season movements of individual blue whales in the eastern north Pacific, over distances comparable to or greater than those covered in our study. Satellite-tagged blue whales moved erratically for relatively short periods within presumed upwelling or frontal foraging areas, before moving to alternate potential feeding areas, to which they were presumably drawn by vocalisations of other whales, environmental cues, or memory of prior feeding success (Mate et al. 1999). Similarly, satellitetagged humpback whales Megaptera novaeangliae off the Antarctic Peninsula made frequent movements between alternate feeding areas where residency periods were short (Dalla Rosa et al. 2008). The oceanographic context underlying such movements is often unknown, 
but in a rare example, Benson et al. (2001) explained how a drop in euphausiid density due to a warm water intrusion into Monterey Bay, California, in 1999 probably caused blue whales to move south to the Channel Islands where more favourable conditions supported large euphausiid aggregations.

Such oceanographic dynamics and their effects on prey distribution are undoubtedly at work off southern Australia, yet our knowledge of upwelling dynamics and its effects on prey ecology are inadequate to explain the blue whale movement patterns described here. The whales may arrive from the west and forage eastward through the feeding ground as the season progresses, before retreating westward again toward the season's end. Photo-identification in the Bonney Upwelling has provided resights of blue whales previously identified in the Perth Canyon and Geographe Bay, Western Australia (C. Jenner, C. Burton, M. Morrice, P. Gill unpubl. data), suggesting that they are from a single wide-ranging stock of pygmy blue whales Balaenoptera musculus brevicauda. They may also arrive from Bass Strait to the east, where adult Nyctiphanes australis constituted $87 \%$ of the diet of common diving petrels Pelecanoides urinatrix urinatrix in October (Schumann et al. 2008), prior to the onset of upwelling and arrival of blue whales in the upwelling region. In May 2006, there were few sightings of blue whales or euphausiid surface swarms in our study area, suggesting that whales may have departed when prey concentrations fell below thresholds required for successful foraging. In May of other years, abundant euphausiid swarms were observed after most or all blue whales appeared to have departed, suggesting that departure of the whales may also be cued by physiological readiness for migration, rather than by limited prey resources at the end of the upwelling season.

Acknowledgements. Aerial survey funding was provided by the Australian government under the Natural Heritage Trust, by Santos Ltd and by Beach Petroleum. The Winifred Violet Scott Estate and Margaret Werner also provided financial support. J. Hughes of Santos Ltd deserves special thanks for his support of the project. We thank the many observers who assisted in surveys, particularly S. McKay, G. Palmeri, D. Glasgow, C. Levings, D. Levings, M. Watson, M. Garcia, M. Tarzia, and G. McKenzie, as well as the pilots of Geelong Aviation. Dr. R. McCauley provided access to additional temperature logger data. Thanks to Prof. G.Quinn for his advice on modelling. Thanks also to Dr. D. Thiele and 3 anonymous reviewers whose comments greatly improved the manuscript. Remotely sensed SST and SSC data was freely obtained online using NASA's Giovanni tool.

\section{LITERATURE CITED}

Alling A, Dorsey EM, Gordon JCD (1991) Blue whales (Balaenoptera musculus) off the northeast coast of Sri Lanka: distribution, feeding and individual identification. In: Leatherwood S, Donovan GP (eds) Cetaceans and ceta- cean research in the Indian Ocean Sanctuary. Marine Mammal Tech Rep No. 3. United Nations Environment Programme, Nairobi, p 247-258

Bailey H, Mate BR, Palacios DM, Irvine L, Bograd SJ, Costa DP (2009) Behavioural estimation of blue whale movements in the northeast Pacific from state-space model analysis of satellite tracks. Endang Species Res 10:93-106

Baumgartner MF, Mate BR (2003) Summertime foraging ecology of north Atlantic right whales. Mar Ecol Prog Ser 264: 123-135

Benson SR, Croll DA, Marinovic B (2001) Whales, krill, and variability of two coastal upwelling centers. Quality Review Board Minutes of Meeting 7. Tech Rep No. 01-1. Monterey Bay National Marine Sanctuary, Monterey

Blackburn M (1980) Observations on the distribution of Nyctiphanes australis Sars (Crustacea, Euphausiidae) in Australian waters. CSIRO Division of Fisheries and Oceanography Report 119. CSIRO, Sydney

Bradford JM, Chapman B (1988) Nyctiphanes australis (Euphausiacea) and an upwelling plume in western Cook Strait, New Zealand. N Z J Mar Freshw Res 22:237-247

> Bradford-Grieve JM, Murdoch RC, Chapman BE (1993) Composition of macrozooplankton assemblages associated with the formation and decay of pulses within an upwelling plume in greater Cook Strait, New Zealand. N Z J Mar Freshw Res 27:1-22

> Branch TA, Stafford KM, Palacios DM, Allison C and others (2007) Past and present distribution, densities and movements of blue whales Balaenoptera musculus in the southern hemisphere and northern Indian Ocean. Mammal Rev 37:116-175

> Broitman BR, Kinlan BP (2006) Spatial scales of benthic and pelagic producer biomass in a coastal upwelling system. Mar Ecol Prog Ser 327:15-25

Burnham KP, Anderson DR (2002) Model selection and multimodel inference: a practical information-theoretic approach, 2nd edn. Springer-Verlag, New York, NY

Burtenshaw JC, Olesen EM, Hildebrand JA, McDonald MA, Andrew RK, Howe BM, Mercer JA (2004) Acoustic and satellite remote sensing of blue whale seasonality and habitat in the northeast Pacific. Deep-Sea Res II 51: 967-986

Butler A, Althaus F, Furlani D, Ridgway K (2002) Assessment of the conservation values of the Bonney Upwelling area. A component of the Commonwealth Marine Conservation Assessment Program 2002-2004. Report to Environment Australia. CSIRO Marine Research, Hobart

Cai W, Lennon GW (1993) An analytical shelf-ocean coupled model for the Bonney Coast Upwelling. Estuar Coast Shelf Sci 37:343-369

Calambokidis J, Steiger GH, Cubbage JC, Balcomb KC and others (1990) Sightings and movements of blue whales off central California 1986-88 from photo-identification of individuals. Rep Int Whal Commn (Spec Issue 12):343-348

Calambokidis J, Barlow J, Ford JKB, Chandler TE, Douglas AB (2009) Insights into the population structure of blue whales in the eastern north Pacific from recent sightings and photographic identification. Mar Mamm Sci 25: $816-832$

Connor RC (2000) Group living in whales and dolphins. In: Mann J, Connor RC, Tyack PC, Whitehead H (eds) Cetacean societies. Field studies of dolphins and whales. University of Chicago Press, Chicago, p 199-218

$>$ Croll DA, Marinovic B, Benson S, Chavez FP, Black N, Termullo R, Tershy BR (2005) From wind to whales: trophic links in an upwelling ecosystem. Mar Ecol Prog Ser 289: $117-130$ 
Dalla Rosa L, Secchi ER, Maia YG, Zerbini AN, HeideJørgensen MP (2008) Movements of satellite-tagged humpback whales on their feeding ground along the Antarctic Peninsula. Polar Biol 31:771-778

Doniol-Valcroze T, Berteaux D, Parouche P, Sears R (2007) Influence of thermal fronts on habitat selection by four rorqual whales species in the Gulf of St. Lawrence. Mar Ecol Prog Ser 335:207-216

Etnoyer P, Canny D, Mate B, Morgan L (2004) Persistent pelagic habitats in the Baja California to Bering Sea (B2B) ecoregion. Oceanography 17:90-101

- Etnoyer P, Canny D, Mate B, Morgan L, Ortiz JG, Nichols WJ (2006) Sea surface temperature gradients across blue whale and sea turtle foraging trajectories off the Baja California Peninsula, Mexico. Deep-Sea Res II 53:340-358

Fiedler PC, Reilly S, Hewitt RP, Demer D and others (1998) Blue whale habitat and prey in the Channel Islands. DeepSea Res II 45:1781-1801

Friedlaender AS, Halpin PN, Qian SS, Lawson GL, Wiebe PH, Thiele D, Read AJ (2006) Distribution of whales in relation to prey and oceanographic processes in the inner shelf waters of the western Antarctic Peninsula. Mar Ecol Prog Ser 317:297-310

Gill PC (2002) A blue whale (Balaenoptera musculus) feeding ground in a southern Australian coastal upwelling zone. J Cetacean Res Manag 4:179-184

Gill PC (2004) Ecological linkages in the Bonney Upwelling blue whale feeding area. PhD thesis, Deakin University, Warrnambool

Gregr EJ, Trites AW (2001) Predictions of critical habitat for five whale species in the waters of coastal British Columbia. Can J Fish Aquat Sci 58:1265-1285

Grémillet D, Lewis S, Drapeau L, van der Lingen CD and others (2008) Spatial match-mismatch in the Benguela upwelling zone: Should we expect chlorophyll and seasurface temperature to predict marine predator distributions? J Appl Ecol 45:610-621

Hiby AR, Hammond PS (1989) Survey techniques for estimating abundance of cetaceans. Rep Int Whal Commn (Spec Issue 11):47-80.

Hooge PN, Eichenlaub B (1997) Animal movement extension to ArcView. Version 1.1. U.S. Geological Survey, Alaska Biological Science Center, Anchorage

> Hucke-Gaete R, Osman LP, Moreno CA, Findlay KP, Ljungblad DK (2003) Discovery of a blue whale feeding and nursing ground in southern Chile. Proc R Soc Lond B 271 (Suppl 4): S170-S173

Irvine L, Mate B (2007) Habitat characterisation of blue whales (Balaenoptera musculus) off California. Abstract, 17th Biennial Conference on the Biology of Marine Mammals, Cape Town, South Africa

Kämpf J, Doubell M, Griffin D, Matthews RL, Ward TM (2004) Evidence of a large seasonal coastal upwelling system along the southern shelf of Australia. Geophys Res Lett 31:L09310 doi:10.1029/2003GL019221

Lagerquist BA, Stafford KM, Mate BR (2000) Dive characteristics of satellite-monitored blue whales (Balaenoptera musculus) off the central California coast. Mar Mamm Sci $16: 375-391$

Lavaniegos BE (1996) Vertical distribution of euphausiid life stages in waters adjacent to Baja California. Fish Bull 94: 300-312

Levin SA (1992) The problem of pattern and scale in ecology. Ecology 73:1943-1967

Levings AH, Gill PC (2010) Water temperature and its effect on the ecology of the southern Australian giant crab Pseudocarcinus gigas. In: Kruse GH, Eckert GL, Foy RJ,
Lipcius RN, Sainte-Marie B, Stram DL, Woodby D (eds) Biology and management of exploited crab populations under climate change. Alaska Sea Grant College Program, University of Alaska Fairbanks, Fairbanks

Lewis RK (1981) Seasonal upwelling along the south-eastern coastline of South Australia. Aust J Mar Freshw Res 32: $843-854$

Mate BR, Lagerquist BA, Calambokidis J (1999) Movements of north Pacific blue whales during the feeding season off southern California and their southern fall migration. Mar Mamm Sci 15:1246-1257

McClatchie S, Middleton JF, Ward TM (2006) Water mass analysis and alongshore variation in upwelling intensity in the eastern Great Australian Bight. J Geophys Res 111: C08007 doi:10.1029/2004JC002699

> Middleton JF, Bye JAT (2007) A review of the shelf-slope circulation along Australia's southern shelves: Cape Leeuwin to Portland. Prog Oceanogr 75:1-41

Middleton JF, Cirano M (2002) A northern boundary current along Australia's southern shelves: the Flinders Current. J Geophys Res 107(C9):3129 doi:10.1029/2000JC000701

Moore SE, Watkins WA, Daher MA, Davies JR, Dahlheim ME (2002) Blue whale habitat associations in the northwest Pacific: analysis of remotely-sensed data using a geographical information system. Oceanography 15:20-25

Morrice MG, Gill PC, Hughes J, Levings AH (2004) Summary of aerial surveys for the Santos Ltd EPP32 seismic survey, 2-13 December 2003. Report WEG-SO 02/2004 to Santos Ltd. Whale Ecology Group, Deakin University, Warrnambool

Nieblas AE, Sloyan BM, Hobday AJ, Coleman R, Richardson AJ (2009) Variability in biological production in low windforced regional upwelling systems: a case study off southeastern Australia. Limnol Oceanogr 54:1548-1558

O'Brien DP (1988) Surface schooling behaviour of the coastal krill Nyctiphanes australis (Crustacea: Euphausiacea) off Tasmania, Australia. Mar Ecol Prog Ser 42:219-233

Palacios DM (1999) Blue whale (Balaenoptera musculus) occurrence off the Galápagos Islands, 1978-1995. J Cetacean Res Manag 1:41-51

Piatt JF, Methven DA (1992) Threshold foraging behavior of baleen whales. Mar Ecol Prog Ser 84:205-210

> Pitcher GC, Boyd AJ, Horstman DA, Mitchell-Innes BA (1998) Subsurface dinoflagellate populations, frontal blooms and the formation of red tide in the southern Benguela upwelling system. Mar Ecol Prog Ser 172: 253-264

Quinn GP, Keough MJ (2002) Experimental design and data analysis for biologists. Cambridge University Press, Melbourne

Redfern JV, Ferguson MC, Becker EA, Hyrenbach KD and others (2006) Techniques for cetacean-habitat modelling. Mar Ecol Prog Ser 310:271-295

> Rennie S, Hanson CE, McCauley RD, Pattiararchi C and others (2009) Physical properties and processes in the Perth Canyon, Western Australia: links to water column production and seasonal pygmy blue whale abundance. J Mar Syst 77:21-44

$>$ Ritz DA (1994) Social aggregation in pelagic invertebrates. Adv Mar Biol 30:155-216

> Ritz DA, Hosie GW, Kirkwood RJ (1990) Diet of Nyctiphanes australis (Crustacea: Euphausiacea). Aust J Mar Freshw Res 41:365-374

> Schahinger RB (1987) Structure of coastal upwelling events observed off the south-east coast of South Australia during February 1983-April 1984. Aust J Mar Freshw Res 38: $439-459$ 
Schumann N, Arnould JPY, Dann P (2008) Diet of common diving-petrels (Pelecanoides urinatrix urinatrix) in southeastern Australia during chick rearing. Waterbirds 31: 620-624

Seaman DE, Powell RA (1996) An evaluation of the accuracy of kernel density estimators for home range analysis. Ecology 77:2075-2085

Sims DW, Quayle VA (1998) Selective foraging behaviour of basking sharks on zooplankton in a small-scale front. Nature 393:460-463

Smith SC, Dunstan P, Au D, Baker KS, Dunlap EA (1986) Distribution of cetaceans and sea-surface chlorophyll concentrations in the California Current. Mar Biol 91:385-402

Stafford KM, Citta JJ, Moore SE, Daher MA, George JE (2009) Environmental correlates of blue and fin whale call detections in the north Pacific Ocean from 1997 to 2002. Mar Ecol Prog Ser 395:37-53

Stevick PT, Incze LS, Kraus SD, Rosen S, Wolff N, Baukus A (2008) Trophic relationships and oceanography on and around a small offshore bank. Mar Ecol Prog Ser 363: $15-28$

Thiele D, Chester ET, Moore SE, Širovic A, Hildebrand JA, Friedlaender AS (2004) Seasonal variability in whale encounters in the western Antarctic Peninsula. Deep-Sea Res II 51:2311-2325

Tynan CT (1998) Ecological importance of the southern boundary of the Antarctic Circumpolar Current. Nature 392:708-710

Tynan CT, Ainley DG, Barth JA, Cowles TJ, Pierce SD, Spear LB (2005) Cetacean distributions relative to ocean pro- cesses in the northern California Current system. DeepSea Res II 52:145-167

van Ruth P (2009) Spatial and temporal variation in primary and secondary productivity in the eastern Great Australian Bight. PhD thesis, University of Adelaide

- Ward TM, Mcleay LJ, Dimmlich WF, Rogers PJ and others (2006) Pelagic ecology of a northern boundary current system: effects of upwelling on the production and distribution of sardine (Sardinops sagax), anchovy (Engraulis australis) and southern bluefin tuna (Thunnus maccoyii) in the Great Australian Bight. Fish Oceanogr 15:191-207

Watkins J (2000) Aggregation and vertical migration. In: Everson I (ed) Krill. Biology, ecology and fisheries. Blackwell Science, Oxford, p 80-102

Whitehead H, O'Brien K, Worm B (2010) Diversity of deepwater cetaceans and primary productivity. Mar Ecol Prog Ser 408:1-5

> Wieters EA, Kaplan DM, Navarrete SA, Sotomayor A, Largier J, Neilsen KJ, Véliz F (2003) Alongshore and temporal variability in chlorophyll a concentration in Chilean nearshore waters. Mar Ecol Prog Ser 249:93-105

Williams R, Fragopolou N (1985) Vertical distribution and nocturnal migration of Nyctiphanes couchii (Crustacea: Euphausiaceae) in relation to the summer thermocline in the Celtic Sea. Mar Biol 89:257-262

Wood LW, Naef-Daenzer B, Prince PA, Croxall JP (2000) Quantifying habitat use in satellite-tracked pelagic seabirds: application of kernel estimation to albatross locations. J Avian Biol 31:278-286 


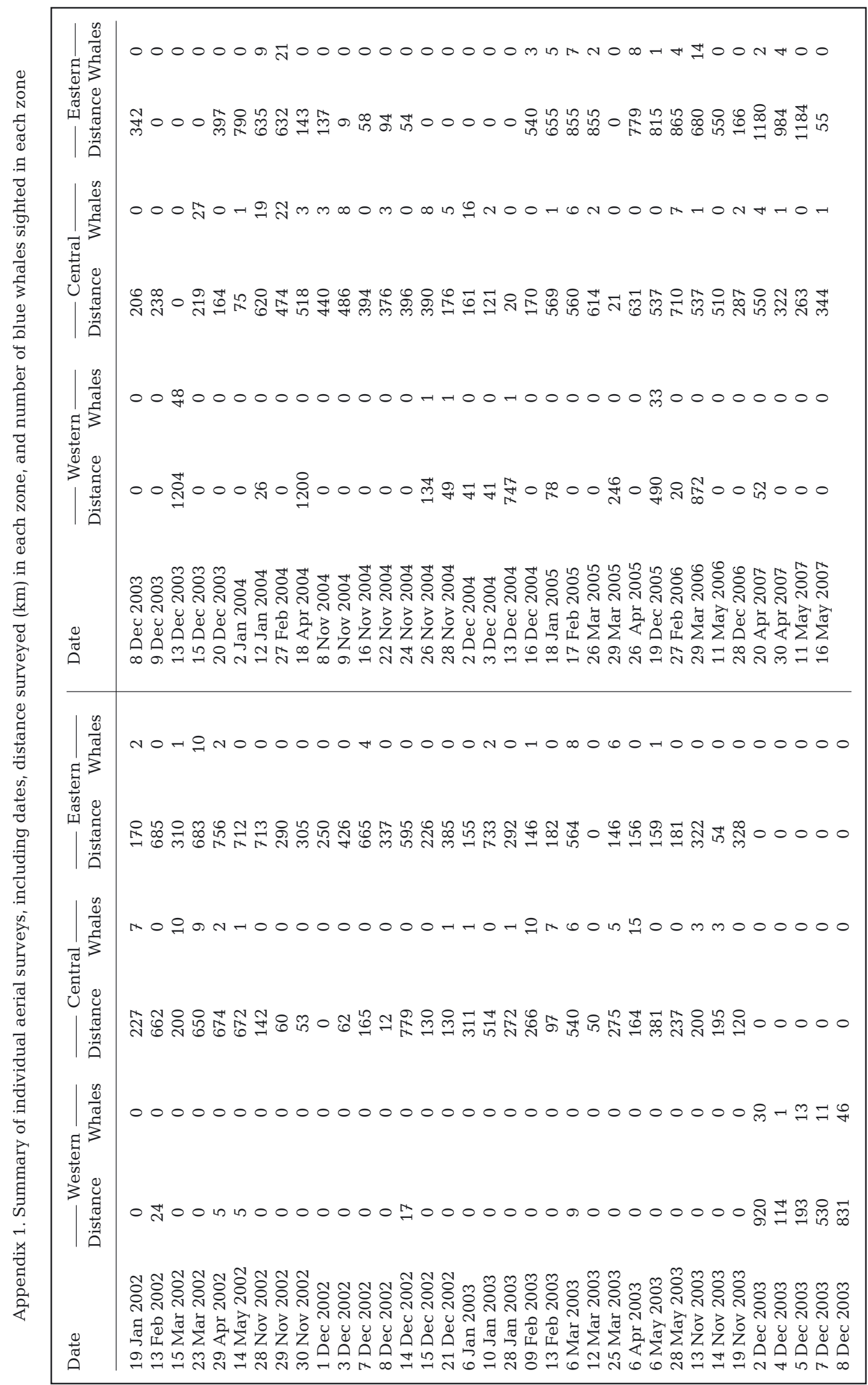

